\title{
Olive Leaf Extract as a New Topical Management for Oral Mucositis Following Chemotherapy: A Microbiological Examination, Experimental Animal Study and Clinical Trial
}

\author{
Khadija Muhamed Ahmed ${ }^{1}$, Nazar Talabani ${ }^{1}$ and Tagreed Altaei ${ }^{2 *}$ \\ ${ }^{1}$ College of Dentistry, University of Sulaimani, Iraq \\ ${ }^{2}$ Department of Pharmacology and Toxicology, College of Pharmacy, Hawler Medical University, Iraq
}

\begin{abstract}
Oral mucositis is a common complication of intensive cancer chemotherapy and radiotherapy. Olive leaf extract was investigated through microbiological, experimental animal studies and clinical trial. The results were compared with the action of benzydamine $\mathrm{HCl}$ as positive control and normal saline as negative control.

Thirty patients under intensive chemotherapeutic treatment were included in the microbiological part of the study for assessment of the oral flora changes, and the antimicrobial activity of olive leaf and benzydamine $\mathrm{HCl}$ against preisolated microoganisms were studied. Oral mucositis was induced through a combination of systemic administration of 5-fluorouracil as chemotherapeutic agent and mild abrasion of the left buccal mucosa of Forty-five male albino rats. An evaluation of the healed buccal mucosa was performed histologically under light microscope at days 7, 9 and 14 of the experiments. In the clinical part of the study, 62 cancer patients receiving intensive chemotherapy were randomized to receive olive leaf extract, benzydamine $\mathrm{HCl}$ or placebo local treatment for two weeks in a three period crossover design. WHO toxicity grading and OMAS mucositis score were applied at days 1 , 8 and 15 of each cycle.
\end{abstract}

In Conclusion; olive leaf extract was effective in reducing the incidence and decreasing the severity of oral mucositis when compared to benzydamine $\mathrm{HCl}$ and placebo groups. Accordingly we suggest using this medication for oral mucositis as a safe (herbal) and effective treatment modality.

Keywords: Olive leaf; Mucositis

\section{Introduction}

Intensive cancer therapy affects malignant and normal cells with high replication rates particularly in cells of the gastrointestinal tract, which are commonly affected by cytotoxins. Among the clinically important acute side effects is disruption in the function and integrity of the oral mucosa. The consequences of this include severe ulceration and inflammation. The term oral mucositis emerged in the late $1980 \mathrm{~s}$ and coined to describe the adverse effect of radiation and chemotherapy treatments $[1,2]$. Oral mucositis, which leads to disruption in the function and integrity of the oral cavity, is characterized by erythema, oedema, bleeding, ulceration, and pseudomembrane formation [3].

The tissue alteration usually develops on non-keratinized surfaces, such as cheek, labial mucosa, floor of the mouth, soft palate and ventral and lateral surfaces of the tongue. Symptoms of mucositis vary from pain and discomfort to an inability to tolerate food or fluids. The pain associated with this condition may limit food intake and often requires treatment with narcotic analgesics [4,5]. Sometimes modification of the therapeutic regimen may occur such as change of the dose or even discontinuation of chemotherapy and these of course affects the antineoplastic treatment $[6,7]$.

The incidence and severity of mucositis varies from patient to patient, which also varies with different treatment regimen. The current head and neck radiotherapy protocols have a mucositis incidence of $85-100 \%$ [8]. The incidence of mucositis can approach $90-100 \%$ in patients receiving aggressive myeoloablative chemotherapy, and in $40 \%$ of patients with solid tumor who have chemotherapy-induced myelosuppression [1,9].

Secondary infection of mucosal ulcers are seen in severe mucositis and can provide a port of entry for micoorganisms into the circulation which can lead to life-threatening septicaemia, especially in myelosuppressed patients $[1,3]$.

The pathogenesis of mucositis is far more complex than the historical view that it simply results from the non-specific direct effects of radiation or chemotherapy on rapidly dividing mucosal basal cells. Mucositis appears to involve five biological phases [10]: (i) Initiation, (ii) Up-regulation and generation of messenger signals (iii) Signal amplification, (iv) Ulceration and (v) Healing. With this understanding, one can select and target particular mediators responsible for the mucositis [5,11].

It is generally accepted that oral mucositis is multifactorial in nature. Cancer treatment factor such as type and dosage of chemotherapy and patient's-related factors are all thought to have a major impact on oral mucositis $[10,12,13]$. Chemotherapeutic drugs that are cellcycle specific interfering with either DNA, RNA, or protein synthesis are associated with an increased risk of oral mucositis. Methotrexate, etoposide and melphalan, that are secreted in the saliva, are also associated with a high rate of severe oral mucositis [14].

*Corresponding author: Tagreed Altaei D, Assistant Professor, Department of Pharmacology and Toxicology, College of Pharmacy, Hawler Medical University, Iraq Tel: 00964750 4941834; E-mail: tagreedaltaei@yahoo.com

Received July 02, 2013; Accepted September 26, 2013; Published Septembe 30, 2013

Citation: Ahmed KM, Talabani N, Altaei T (2013) Olive Leaf Extract as a New Topical Management for Oral Mucositis Following Chemotherapy: A Microbiological Examination, Experimental Animal Study and Clinical Trial. Pharmaceut Anal Acta 4: 269. doi: 10.4172/2153-2435.1000269

Copyright: ( 2013 Ahmed KM, et al. This is an open-access article distributed under the terms of the Creative Commons Attribution License, which permits unrestricted use, distribution, and reproduction in any medium, provided the original author and source are credited. 
Many treatment options are available to prevent and treat oral mucositis, but none of them can completely prevent or properly treat mucositis [5]. Several studies have been developed to evaluate a number of agents with direct action on the epithelial proliferation of the oral mucosa such as transforming growth factor-beta 3 (TGF- $\beta 3$ ), keratinocyte growth factor (KGF) (Palifermin) and granulocyte macrophage colony stimulating factor (GM-CSF). Several interventions have been evaluated with the aim of reducing the impact of oral mucositis, these include, oral hygiene care with mouth rinses and antimicrobial agents to prevent secondary infections; use of antiinflammatory drugs, topical and systemic analgesics for pain relief; topical antioxidants; mucosal-coating agents; vitamins and cryotherapy with ice chips. All these, however, are considered as palliative treatments. Most of these studies do not present consistent results and the evaluated therapies do not add significant benefits to prevention and/ or treatment of mucositis. Therefore, the search for new therapies that act, not only on symptoms relief, but also on the prevention and effective reduction of oral mucositis is extremely important [15].

Olive leaf extract is a natural product with antioxidant [16], antiinflammotry [17], and antimicrobial activities against bacteria [18], virus [19], fungi and mycoplasma [20,21]. Olive leaf extract have also been traditionally used to treat and prevent hypertension and diabetes for their hypoglycemic, antiseptic and diuretic properties [22-25]. More recent study demonstrated the anticancer effects of olive leaf extract $[26,27]$ but nothing have been said about the treatment or prevention of oral mucositis. The present study is designed to study the therapeutic effect of olive leaf extract as regards the prevention and/ or treatment of oral mucositis. The aims of study;

- To evaluate the effect of olive leaf extract as a local treatment for chemotherapy induced mucositis in humans and experimental animals.

- To study the antimicrobial effects of olive leaf extract on the oral microflora in cancer patients under chemotherapy.

- To study the anti-inflammatory effect of olive leaf extract on oral mucositis in humans and experimental animals.

\section{Materials and Methods}

The present study consists of three parts, microbiological, animal and clinical studies.

\section{The microbiological study}

Setting and patients: This part of the study was conducted in Hiwa Hospital in Suliamani city from January to April 2009. Thirty patients were included in the study; they were all consecutive cancer patients (children and adults) who were under intensive cancer treatment. All procedure was conducted in accordance with the guidelines approved by our local ethical committee.

\section{Inclusion criteria}

1. Patients receiving intensive cancer treatment (high dose of single cytotoxic drug or combinations of multiple cytotoxic drugs).

2. Absence of prophylactic local treatment for mucositis.

3. Parents or patient's signature on an informed consent form

\section{Exclusion criteria}

1. Patients under non- intensive chemotherapeutic treatment.

2. Patient taking prophylactic local medication for oral mucositis.
Collection of mouth wash samples: To obtain mouth wash samples, the patients was asked to rinse their mouth with $10 \mathrm{ml}$ of isotonic saline for $30 \mathrm{~s}$ and spit into a sterile leak proof container (disposable cup) according to the methodology prescribed by Spijkervet et al. and Stokman et al. [28,29]. Cool-box was used to transfer the mouthwash immediately to the laboratory for culturing.

Four samples of mouthwash were obtained from each patient; one sample before the start of chemotherapy and three other samples were taken one week, two weeks and three weeks after chemotherapy.

Scoring and monitoring oral mucositis: The mucositis was scored according to the Oral Mucositis Assessment Scale (OMAS) and World Health Organization score [30,31] prior to taking the mouthwash. The two scoring systems were used to be able to compare outcomes with findings from literature, which use either scoring system.

The OMAS mucositis score measures nine sites in the mouth, for erythema, pseudomembranes or ulcerations (mean score ranges from 0 to 5). The WHO mucositis score is as follows: grade $0=$ normal, no mucositis; grade $1=$ soreness and erythema; grade $2=$ erythema, ulcer, can eat solids; grade $3=$ ulcers, require liquid diet only; grade $4=$ alimentation not possible.

Activation of mouth microbial flora and viable plate counting: This part of the study was carried out in the Department of Biology, College of Science/University of Sulaimani. One $\mathrm{ml}$ of the mouth wash sample was inoculated in Brain Heart Infusion (BHI) broth and incubated at $37^{\circ} \mathrm{C}$ for $24 \mathrm{~h}$ for activation. After activation, the isolation was performed through streaking on Mannitol salt agar for Staphylococci, MacConkey agar for Gram-negative bacteria, blood agar for Streptococci and Sabauroud dextrose agar for fungi.

Standard plate count was used for counting mouth wash microbial flora throughout tenfold dilution method; four plates were labeled as $10^{-2}, 10^{-4}, 10^{-5}$ and $10^{-6} .1 \mathrm{ml}$ of each mouth wash dilution was distributed on the respective plates as indicated. Petri plates were incubated at $37^{\circ} \mathrm{C}$ for $24 \mathrm{~h}$ and monitored for the appearance of colonies. The plates were counted and calculated according to the following equation:

Colony forming unit $(\mathrm{CFU}) / 1 \mathrm{ml}$ of mouthwash=count/plate dilution used

\section{Isolation and identification of bacteria}

Isolation: Different culture media were used for the isolation of each of the selected bacteria and fungi on their selective medium. MacConkey agar for Gram-negative bacteria, Mannitol salt agar for Staphylococci, and Blood agar for Streptococci (by using candle jar) incubated at $3^{\circ} \mathrm{C}$ for $24 \mathrm{~h}$ while Sabouraud's dextrose agar incubated at $25^{\circ} \mathrm{C}$ for $72 \mathrm{~h}$ was for fungi, the grown colonies were purified and identify.

Identification of isolates: Identification of bacterial species was performed according to Bergey's manual of determinative bacteriology and other references [32-35].

Cultural characteristics: When a microorganism is grown on a culture medium, it exhibits specific growth patterns such as consistency, color, odor, fermentation, colony elevation and diameter, which can be used in identifying the bacteria. The different culture medium and the microorganism that they isolate is given below.

- MacConkey agar-Isolation and differentiation between lactose fermenter and non-lactose fermenter.

- Blood agar- Evidence of blood hemolysis 
- Mannitol salt agar-Isolation and differentiation between mannitol fermenter and non-mannitol fermenter (Staphylococcus sp.)

- abouraud's dextrose agar-Isolation of Candida sp.

\section{Microscopic examination}

Gram stained technique: A small amount of bacterial culture was taken on a glass slide by mixing a colony of tested bacterium with a drop of distilled water, which was allowed to dry in air, and then heated to fix them to the glass, a thin smear was made, Gram stained, and examined under $\times 100$ power as described by Morello et al. [36].

\section{Biochemical reactions}

Biochemical tests were performed for further identification of bacterial isolates at the levels of species and subspecies.

Oxidase test: Filter papers saturated with oxidase reagent $(1 \%$ dimethyl-p-phenylene-diamine-dihydrochloride) were placed in a Petri dish; colony from tested organism was transferred to the filter paper and rubbed onto the reagent with an applicator stick. The appearance of purple color in $10 \mathrm{~s}$ indicates a positive reaction as described by Mahon and Manuselis [34].

Catalase test: Wooden applicator stick was used to transfer some of the growth from the subculture plate and rubbed on a small area of the glass microscope slide to perform catalase test by adding a drop of $3 \%$ hydrogen peroxide $\left(\mathrm{H}_{2} \mathrm{O}_{2}\right)$. The release of oxygen bubbles indicates the presence of catalase according to the method described by Mahon and Manuselis [34].

Coagulase test: This was carried out using tube methods. The plasma was diluted to 1:10 with physiological saline and $5 \mathrm{ml}$ of diluted plasma were added to each of the two test tubes. $0.1 \mathrm{ml}$ each of broth medium and sterile medium was added to the different test tube incubated at $37^{\circ} \mathrm{C}$. Clot formation in the test tube containing tested bacterium as described by Morello et al. [36] indicated positive result.

Optochin susceptibility test: This susceptibility test was used for differentiating Streptococcus pneumoniae (Pneumococci) from Viridans Streptococci, since S. pneumoniae is sensitive to this test as described by Morello et al. [36].

Novobiocine susceptibility test: This disk susceptibility test was used for differentiating Staphylococcus epidermidis from Staphylococcus saprophyticus, since $S$. epidermidis is sensitive to this test as described by Morello et al. [36].

Use of API system: Methodologies were performed in accordance with the manufacturer's instructions prepared by bio-Mérieux and Remel Company.

- API 20 STREP strip: This was used for identification of Streptococci

- API Staph: This was used for identification of Staphylococci

- API 20 AUX strip: This was used for identification of Candida

- Rapid ID E: This was used for identification of Enterobacteriaceae

Antimicrobial activities of olive leaf extract and benzydamine HCl: Study of minimal inhibitory concentration (MIC) of olive leaf extract and benzydamine $\mathrm{HCl}$ in vitro was determined by twofold dilution method using Mueller-Hinton broth (for bacteria) and Sabouraud's dextrose broth (for Candida) in two replicates as recommended by National Committee for Clinical Laboratory Standard (NCCLS, 2003) [37]. The ratio of both olive leaf extract and benzydamine $\mathrm{HCl}$ in test medium gave the following required concentrations; $333,166.5,83.25,41.625 \mathrm{mg} / \mathrm{ml}$ and $1.5,0.75,0.375$, $0.1875 \mathrm{mg} / \mathrm{ml}$, respectively for all isolated bacteria and fungi in this study.

Each set of test tubes contains broth and oral mouth medicament wash inoculated with $0.1 \mathrm{ml}$ of the tested bacterium and yeast which was compared to $0.5 \mathrm{McF}$ arland standard corresponding to $1.5 \times 10^{8}$ cells/ $\mathrm{ml}$, then test tubes were incubated at $37^{\circ} \mathrm{C}$ for $24 \mathrm{~h}$ for bacteria and at $25^{\circ} \mathrm{C}$ for $72 \mathrm{~h}$ for the yeast. Turbidity in the broth test tube was observed visually (MIC values were recorded as the lowest concentration of the olive leaf and benzydamine $\mathrm{HCl}$ ); both had no visible turbidity.

MBC and MFC are defined as the lowest concentration where no bacterial (bactericidal concentration) and fungal growth (fungicidal concentration) was observed. Both were determined by transferring $0.1 \mathrm{ml}$ of MIC test tubes content and spread on Mueller-Hinton agar and Sabouraud's dextrose agar for bacteria and fungi, respectively. After the incubation time, MBC and MFC values were recorded for bacterial and fungal isolates as the lowest concentration of olive leaf extract and benzydamine $\mathrm{HCl}$ that had bactericidal and fungicidal activity.

Statistical analysis: The collected data for the samples were analysed by SPSS (Statistical Package for Social Sciences-13) to explore simple analysis of variables (frequency, percentage and means). The association between variables was done using different statistical test these include ANOVA (analysis of variance), correlation coefficient and chi square test. The $\mathrm{P}$ value $<0.05$ was regarded as a significant level.

\section{The animal study}

\section{Materials}

The following materials were used in this part of the study:

1. Benzydamine Hydrochloride $(0.15 \mathrm{~g} / 100 \mathrm{ml})$ Manufactured by EPICO, Egypt; under Licence of F. Angelini Italy ${ }^{\circledR}$.

2. 5-Fluorouracil $(1000 \mathrm{mg} / 20 \mathrm{ml})$ "EBEWE" Pharma Untertach, Austria.

3. Olive Leaf ( $333 \mathrm{mg} / \mathrm{ml}$ Olea europaea), Manufactured by St Francis Herb Farm Inc. Combermere, Canada.

4. Normal Saline $0.9 \% \mathrm{w} / \mathrm{v}$, sodium chloride B.P $500 \mathrm{ml}$ (Pharmaceutical Solutions Industry, Jeddah, Kingdom of Saudia Arabia).

\section{Diethyl ether (Grainland Chemical Company, UK).}

\section{Methods}

Animal preparation: Forty-five male albino rats (Rattus norvegicus), 70-80 days old and having an average of $250 \mathrm{~g}$ were housed in a room at the Animal House, College of Science, Department of Biology/University of Sulaimani, where ethics was approved. The room

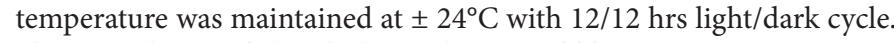
The animals were fed with diet and water ad libitum.

Oral mucositis model: The animals' model for chemotherapyinduced oral mucositis was based on the modified method described by Sonis et al. [38]. The rats received two intraperitonial injections of 5 -fluorouracil $(60 \mathrm{mg} / \mathrm{kg})$ on day 0 and day 2 . To induce mucosal ulceration, rats were anesthetised with diethyl ether and their left cheeks were exposed and lightly scratched with a small $0.8 \mathrm{~mm}$ gage stainless steel orthodontic wire [2×6] strokes on day 1 and day 2 (Figure 1 ). The medicinal mouth washes were applied to the left cheek every 


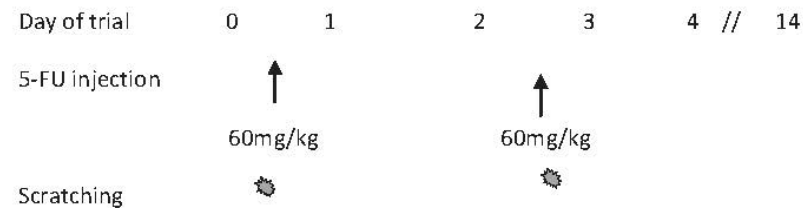

( $2 \times 6$ strokes on day 1 and day 2$)$

Cheek treatment

(Olive leaf, Benzydamine HCL, normal saline)

Figure 1: Schematic representation of the oral mucositis rat trial procedure: continuous treatment.

day from day 2 till day 14 under anaesthesia with diethyl ether. Five drops of each mouthwash were administered into the left cheeks and remained in contact with the abraded area for two minutes. Each animal was weighed daily throughout the experimental period and the ulcers were assessed daily between days 3 and 14 immediately, prior to application of the medicinal mouth washes. Assessment of rat's cheek mucosa includes, measuring the length and width of the ulcer with digital caliper ( $\mathrm{mm}$ ) and photographing the left cheek pouch. The ulcer area was determined by multiplying the highest length with the highest width [4,39-41].

The animals were divided into three groups ( 15 rats per each group and 5 rats in each cage) as follows:

In the first group (group A), normal saline was applied, in the second group (group B) olive leaf extract was applied and in the third group (group C) benzydamine hydrochloride was applied. Throughout the experimental period a total of 13 rats died.

Two rats in each group were killed on day 7, 9 and the remaining animals were killed at day 14. All the treatment procedure was conducted in accordance with the guidelines approved by the local ethical committee for experimental animal use.

Preparation of tissues for histopathological examination: Excisional biopsies from the induced lesions in the left cheek were removed from the animals at day 7, 9 and 14 for histopathological examination. The specimens were fixed in $10 \%$ formalin, dehydrated, cleared and embedded in paraffin. Sections of $5 \mu \mathrm{m}$ thickness were obtained for H\&E staining and examined by light microscopy; images were acquired using a digital camera (Sony, Tokyo, Japan).

Statistical analysis: All measured results were represented as group means and standard errors of the mean. Two-way analysis of variance (two-way ANOVA) was used to find the association between variables as follows:

1. Weight changes among the studied groups and the durations (days) of the experiments.

2. The size of ulcer area among the studied groups on the days of the experiments. The significance level was set at $P<0.05$.

\section{The clinical study}

This part of the study was carried out in Hiwa Oncology Hospital in Sualimani City, from December 2009 to April 2010; sixty-two patients were selected to participate in this part of the study according to the inclusion and exclusion criteria applied for the microbiological part of the study.
Study design: This was a prospective, randomised, double blind placebo controlled cross over study. This design was based on the fact that it is extremely difficult to control all therapy and patient specific variables in a single center study and much more difficult in obtaining sufficient number of participants in the study time period meeting all the inclusion criteria.

Oral treatment regimen: The eligible patients were randomised to receive benzydamine hydrochloride, olive leaf extract or placebo in the form of mouth rinse. This oral treatment was changed in the next chemotherapy cycle for each patient (Cross over design).

The studied drugs were self administered 3-4 times daily for fourteen days starting from the first day of chemotherapy. The patients were asked to rinse their mouth with water prior to application of the oral treatment to remove any remnants of food particles after which they were asked to maintain good oral hygiene by brushing with soft bristle brush daily.

Evaluation of treatment: During the study period, visual evaluation of the tested oral treatment was performed on day 1,8 and 15 of each cycle of chemotherapy. At these days a follow up case sheet was filled for each patient.

Assessment of oral mucositis: The oral mucositis was assessed weekly on day 1, 8 and 15 according to OMAS and WHO scale for oral mucositis assessment (as prescribed in the microbiological part of the study).

Assessment of oral pain, swallowing and feeding: On day 1,8 and 15 of each chemotherapy cycle, the pain associated to oral mucositis and problems in swallowing was scored subjectively [42]. Briefly, patients overall intensity of oral mucositis related pain was rated using $10 \mathrm{~mm}$ visual analog scale (VAS) ranging from $0=$ (no pain) to $10=$ (worst possible pain) and impact on swallowing ranging from no impact in swallowing $(0 \mathrm{~mm})$ to impossible swallowing $(10 \mathrm{~mm})$, respectively. This method of measurement was chosen because it is regarded as simple, specific and reliable for comparing patients' changes within themselves as recorded by Collins et al. [43].

The patient's ability to take food was also assessed by having one multiple-choice question about eating function with four levels of functioning: normal, soft foods only, liquids only or no oral intake possible.

Statistical analysis: Simple descriptive analysis was used to explore different variables (gender, type of tumour and type of drug used).

Different statistical tests were used to find the association between the different variables. The significance level was set at $\mathrm{P}<0.05$ as follows:

1. ANOVA test was to find the mean OMAS mucositis score and duration (days) among the tested drugs. Post hoc test was also used to find the difference of mean OMAS mucositis score between the tested drugs at various week intervals.

2. Kruskall-Wallis (chi square) test was used to find the association between WHO grades and the time (days) among the tested drugs.

3. ANOVA test was used to find the association between pain and difficulty in swallowing on the different days among the tested drugs.

4. Kruskall-Wallis (chi square) test was used to find the association between the feeding patterns of the patients at the time (days) of applying the tested drugs. 
Citation: Ahmed KM, Talabani N, Altaei T (2013) Olive Leaf Extract as a New Topical Management for Oral Mucositis Following Chemotherapy: A Microbiological Examination, Experimental Animal Study and Clinical Trial. Pharmaceut Anal Acta 4: 269. doi: 10.4172/2153-2435.1000269

\section{Results}

\section{The animal study}

Body weight: All animals were weighing daily starting from day zero to day 14. The mean body weights for each group throughout the trial are presented in Figure 2. There was no significant weight difference between treatment groups across days 0 to 12 . At day 14 there was significant weight gain in the treated groups with olive leaf and Benzydamine $\mathrm{HCl}$ of animals as compared with the control groups. A peak body weight loss was recorded at day 7 for all treatment groups. However, weight gain started gradually after day 8 till day 14 .

\section{Macroscopic appearance of the induced ulcers}

The ulcer area: The intraperitoneal administration of 5-FU, followed by mechanical trauma of the cheek mucosa of the rats caused obvious ulcerated lesions from day 3 up to day 14. Measurement of the dimensions of the induced ulcer by digital caliper was carried out from day 3 till day 14 (Table 1 and Figure 3). No significant difference was detected in the dimensions of the ulcerated area in the treated groups from day 3 to day 5, there was insignificant difference between the groups. From day 6 till day 10, there was significant difference in the size of ulcer area between the control groups receiving normal saline

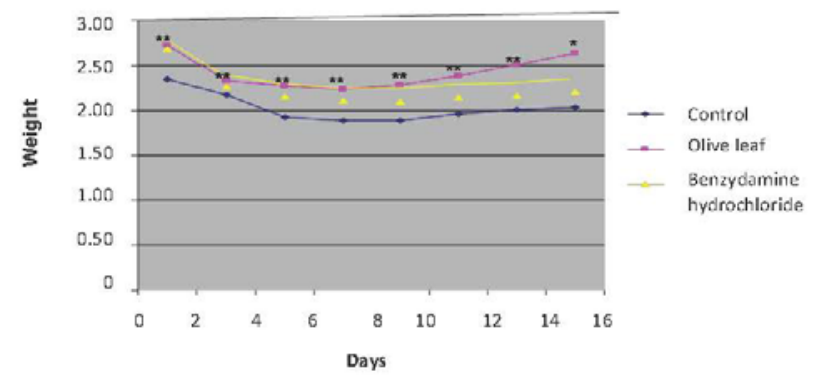

Figure 2: The bodyweight of rats throughout the experimental periods.

\begin{tabular}{|l|c|c|c|c|c|c|}
\hline \multirow{2}{*}{ Groups } & \multicolumn{6}{|c|}{ Ulcer area by $\mathbf{~ m m 2}$ in different days } \\
\cline { 2 - 7 } & $\mathbf{4}$ & $\mathbf{6}$ & $\mathbf{8}$ & $\mathbf{1 0}$ & $\mathbf{1 2}$ & $\mathbf{1 4}$ \\
\hline $\begin{array}{l}\text { Control } \\
\text { (Mean } \pm \text { S.D) }\end{array}$ & $29.7 \pm 6.9^{\star}$ & $30.7 \pm 5.9^{\star \star}$ & $30.1 \pm 4.3^{\star \star}$ & $29.1 \pm 8.6^{\star \star}$ & $27.9 \pm 10.1$ & $23.7 \pm 16.2$ \\
\hline $\begin{array}{l}\text { Olive leaf } \\
\text { (Mean } \pm \text { S.D) }\end{array}$ & $27.6 \pm 6.1$ & $16.3 \pm 6.9$ & $7.2 \pm 4.2$ & $1.6 \pm 1.3$ & $0.00 \pm 0.00$ & $0.00 \pm 0.00$ \\
\hline $\begin{array}{l}\text { Benzydamine } \\
\text { HCl } \\
\text { (Mean } \pm \text { S.D) }\end{array}$ & $27.6 \pm 8.0$ & $15.1 \pm 6.4$ & $7.1 \pm 2.6$ & $1.2 \pm .9$ & $0.00 \pm 0.00$ & $0.00 \pm 0.00$ \\
\hline
\end{tabular}

${ }^{*} P$ value $\geq 0.05,{ }^{* *} P$ value $<0.05$

Table 1: The area of ulcer in the left buccal mucosa of rats at different days.

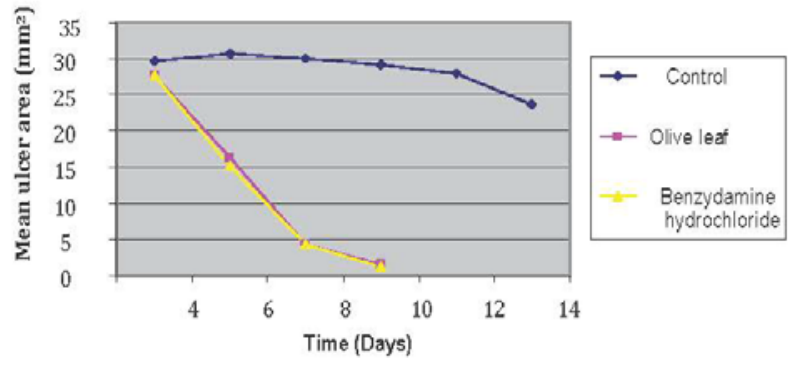

Figure 3: The ulcer area in the treated groups of rats at different days.

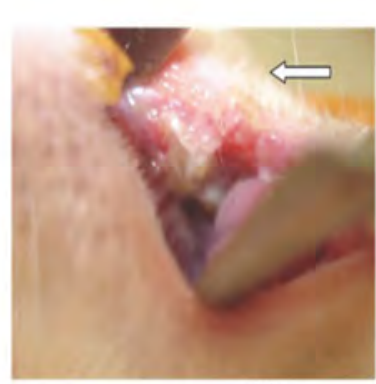

(A)

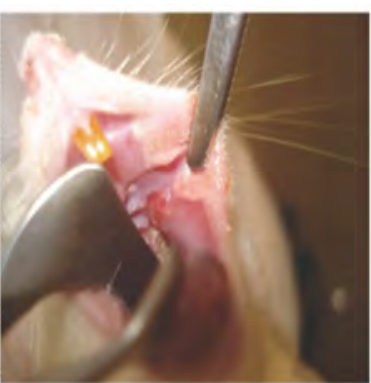

(B)
Figure 4: $A$ and $B$ show the macroscopical appearance of the ulcer in the left buccal mucosa in the control groups of rats at day 7 (arrows indicate the ulcerated area).

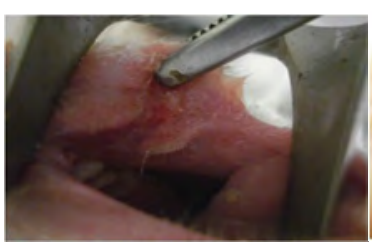

(A)

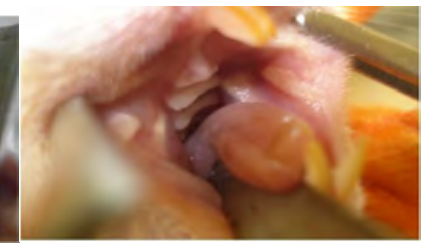

(B)
Figure 5: Macroscopical features of healed ulcers after using olive leaf at day 7 (arrows indicate the healed buccal mucosa of the rats).

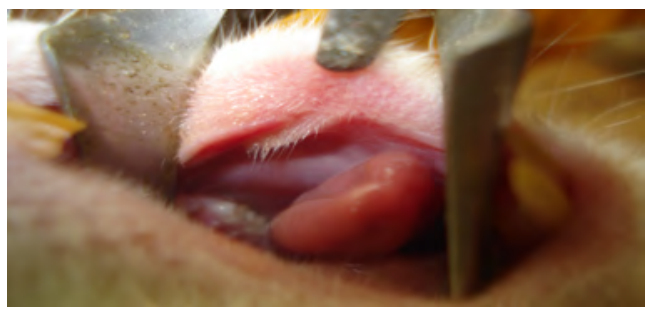

Figure 6: The clinical appearance of the left buccal mucosa of rats at day 7 shows healed ulcer surface in rats treated with benzydamine $\mathrm{HCl}$.

and the olive leaf and benzydamine $\mathrm{HCl}$ groups; the ulcers in the treated groups were smaller than the control groups ( $p$ value was $<0.001$ ). From day 11 till day 14, the induced ulcers were completely healed in the groups treated with olive leaf and benzydamine $\mathrm{HCl}$ while those in the control group showed no evidence of healing.

Gross appearance of the induced ulcers in the experimental animals at the day of sacrifice

Day 7 (5 days after induction): In the control group, the ulcer was evident macroscopically, the ulcerated area showed loss of surface epithelium and exposure of the underlying connective tissues (Figure 4). In the animals treated with olive leaf extract and benzydamine $\mathrm{HCl}$, there was evidence of commenced epithelialization of the surface epithelium and granulation tissue formation in the center of the ulcers (Figures 5 and 6).

Day 9 (7 days after induction): In the control group, the ulcerated buccal mucosa was seen clinically with structureless exudative layer on the ulcerated mucosa (Figure 7). The buccal mucosa of the animals treated with olive leaf and benzydamine $\mathrm{HCl}$ showed conspicuous signs of healing (Figures 8 and 9).

Day 14 (12 days after induction): In the control group, the buccal 
Citation: Ahmed KM, Talabani N, Altaei T (2013) Olive Leaf Extract as a New Topical Management for Oral Mucositis Following Chemotherapy: A Microbiological Examination, Experimental Animal Study and Clinical Trial. Pharmaceut Anal Acta 4: 269. doi: 10.4172/2153-2435.1000269

Page 6 of 18

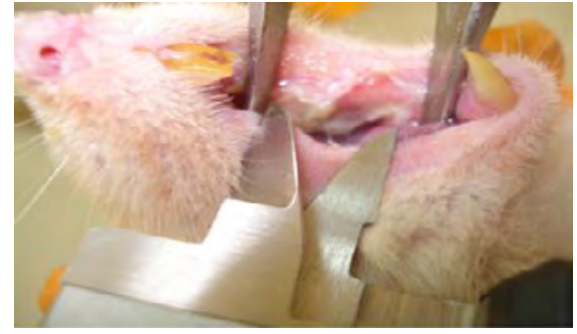

Figure 7: Gross appearance of ulcerated mucosa of left buccal mucosa in the control group at day 9 .

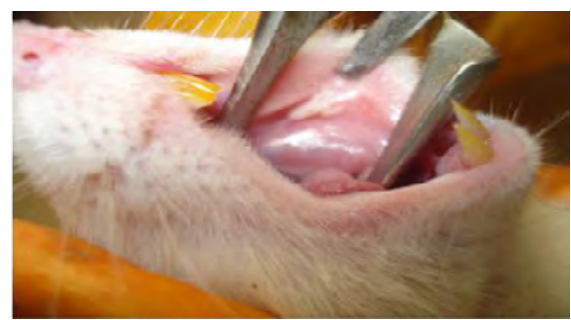

Figure 8: Gross appearance of the healed buccal mucosa after local application of olive leaf at day 9 .

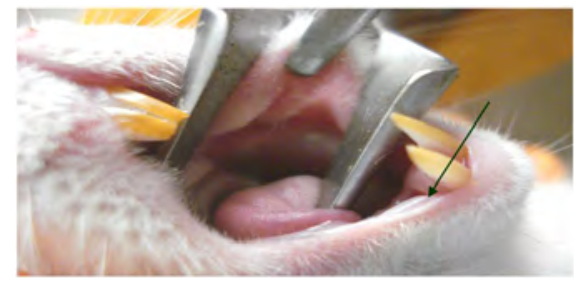

Figure 9: Gross appearance of the healed buccal mucosa in rats treated with benzydamine hydrochloride at day 9 .

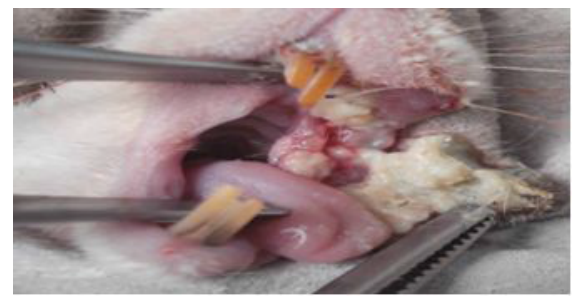

Figure 10: Macroscopical picture of left buccal mucosa, revealing severe ulceration and extensive necrosis in the control groups at day 14.

mucosa showed areas of necrosis and bleeding from the ulcerated surfaces (Figure 10) while in the animals treated with olive leaf extract and benzydamine hydrochloride complete healing was observed (Figures 11 and 12).

Histological appearance of the induced ulcers: Biopsies from the site of the induced lesions on the buccal mucosa were taken from two animals of each group at day 5, 7 and 12 after the local application of the tested drugs (that is, 7, $9 \& 14$ days after the start of chemotherapy). Biopsy samples were fixed in $10 \%$ formalin and prepared for microscopical examination.

\section{Day 7 (5 days after local treatment)}

The control group: In the control group, there was no evidence of healing of the ulcers. Chronic and acute inflammatory cells and dilated blood vessels were visible in the fibrous tissue at the base of the ulcers (Figure 13).

Olive leaf group: In the olive leaf treated group, evidence of complete healing was seen. The sub mucosa was fully covered by stratified squamous epithelium. However, scanty collections of chronic inflammatory cells were visible in the underlying fibrous connective tissue (Figure 14).

Benzydamine $\mathrm{HCl}$ group: In the treated groups with benzydamine

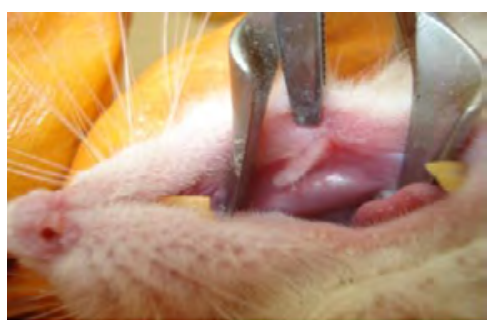

Figure 11: The appearance of healed buccal mucosa of rats at day 14 after application of olive leaf.

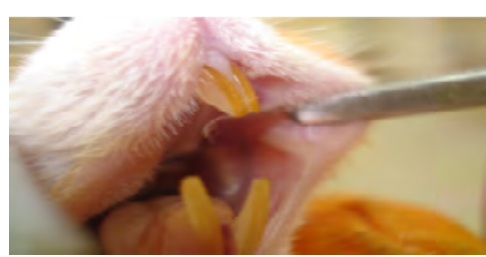

Figure 12: Clinical appearance of healed buccal mucosa at day 14 after local application of benzydamine $\mathrm{HCl}$.
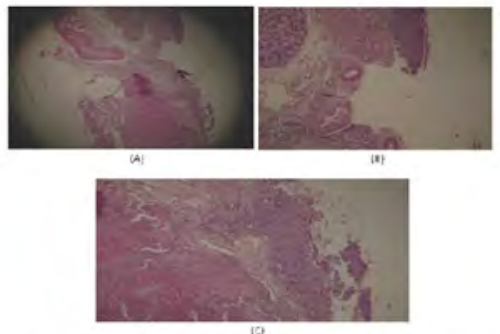

Figure 13: (A, B and $C$ ), shows the micoroscopical features of ulcered mucosa at day 7 , the loss of epithelia is clearly evident in $A$ (arrow indicated the remnant of some epithelia), in B the blood vessels, nerve bundles exposed (see the arrow), in $\mathrm{C}$ ulceration and poorly definition of the epithelial layer in the control groups (see the arrow) [(H\&E stain $\times 40$ for $(A)$ and $\times 100$ for $(B$ and $C)$ ].
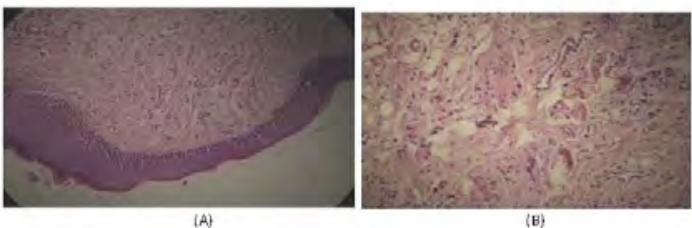

Figure 14: $(A$ and $B)$ shows the microscopical features of animals at day 7 in the olive leaf treaded group. The thin squamous epithelial surface, covered by keratin and the subepithelia contain fibrous tissue and few inflammatory cells [H\&E stain $\times 100$ for $(A)$ and $\times 400$ for $(B)$ ]. 
Citation: Ahmed KM, Talabani N, Altaei T (2013) Olive Leaf Extract as a New Topical Management for Oral Mucositis Following Chemotherapy: A Microbiological Examination, Experimental Animal Study and Clinical Trial. Pharmaceut Anal Acta 4: 269. doi: 10.4172/2153-2435.1000269

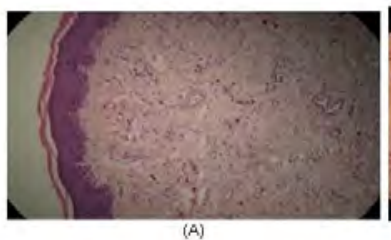

(A)

Figure 15: Microscopical picture of the buccal mucosa of rats at day 7 after applications of benzydamine $\mathrm{HCl}$ revealing the squamous epithelia covered by thin layer of keratin, and the subepithelia contain marked fibrous tissue $[\mathrm{H} \& \mathrm{E}$ stain $\times 100$ for $(\mathrm{A})$ and $\times 400$ for $(B)]$.

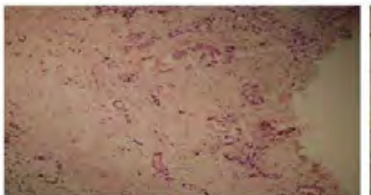

(A)

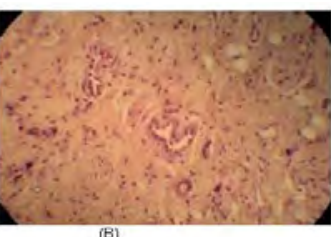

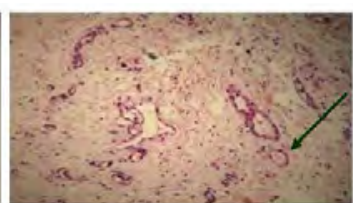

(B)
Figure 16: Histological appearance of the ulcerated mucosa at day 9 in the control groups of rat, the epithelia completely denuded, the subepithelial layer filled with fibrous tissue and blood vessels (arrows show the budding of the blood vessels). [H\&E stain $\times 40$ for $(A)$ and $\times 400$ for $(B)$ ].

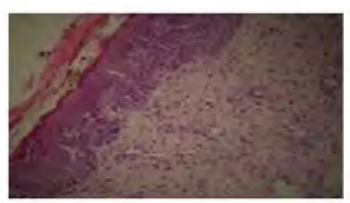

(A)

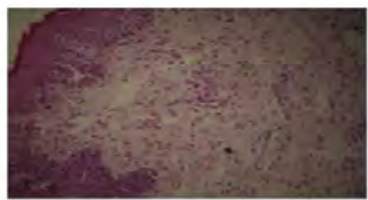

(B)
Figure 17: The microscopical appearance of the buccal mucosa at day 9 after local application of olive leaf, revealing the stratified squamous epithelia covered by keratin with retiridge formation (See the arrows), the subepithelia contain marked collagen fibres. (H\&E stain $\times 100)$.

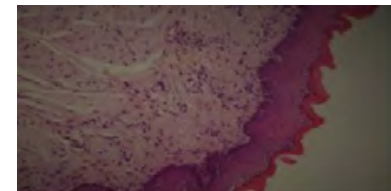

(A)

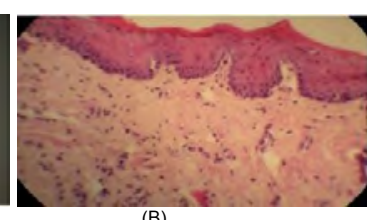

(B)
Figure 18: The histological features of the left buccal mucosa at day 9 in the animal treated with benzydamine $\mathrm{HCl}$. A and B shows the stratified squamous epithelium and formation of retiridges [H\&E stain $\times 40$ for $(A)$ and $\times 100$ for $(B)]$

$\mathrm{HCl}$, complete healing was observed and the histologic findings were similar to that seen in the olive leaf treated group (Figure 15).

\section{Day 9 ( 7 days after local treatment)}

The control group: In the control group, the stratified squamous mucosa appeared to be proliferating and has start covering the exposed connective tissue. The centre of the ulcer was still not covered by epithelium. The fibrous connective tissue showed evidence of proliferation and vascularization. Chronic inflammatory cells were present in small numbers when compared with the 7 day specimens (Figure 16).

Olive leaf group: The covering stratified squamous epithelium showed keratinisation and basal cell proliferation (forming retiridges) (Figure 17).

Benzydamine $\mathbf{H C l}$ group: In the treated groups with benzydamine $\mathrm{HCl}$, similar histologic findings were observed to that of olive leaf treated group (Figure 18).

\section{Day 14 (12 days after local treatment)}

The control group: In the control group ulcerated connective tissue was still not covered by epithelium completely. Evidence of necrosis and degeneration was noticed in the specimens (Figures 19 and 20).

Olive leaf group: In the treated groups with olive leaf, the mucosal surface was totally reepithelialized with hyperkeratinisation and

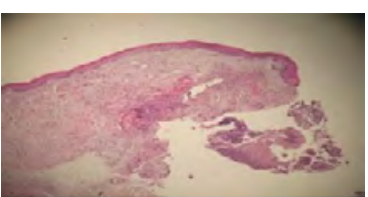

(A)

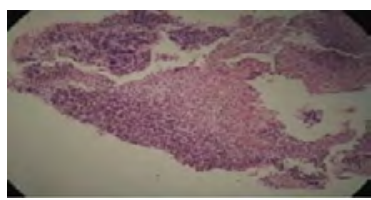

(B)

Figure 19: Microscopical features of oral mucosa in the control groups at day 14 showing the junction between the necrotic area and the healed epithelium, although the healing of damaged epithelium occurred but was not enough to counteract the necrotic area $(A) \cdot \ln B$ the necrotic tissue is present. [H\&E stain $\times 40$ for $(A)$ and $\times 100$ for $(B)$ ]
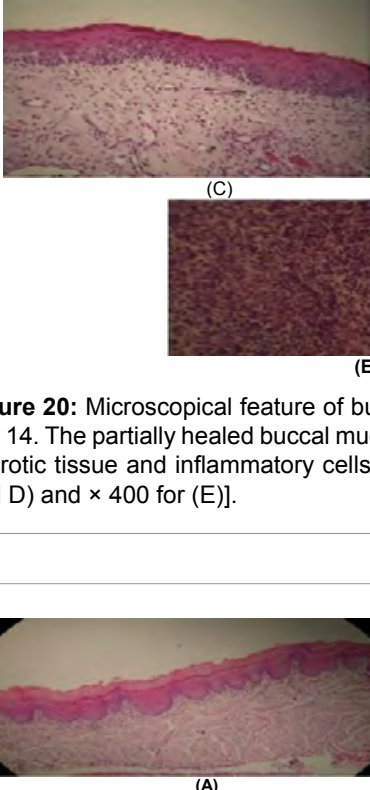

(A)

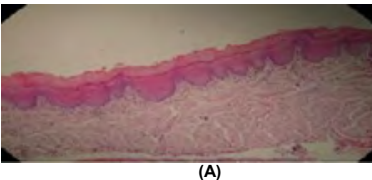

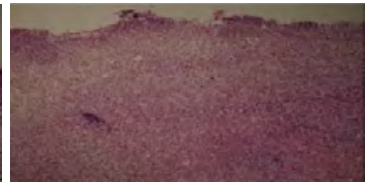

Figure 21: The microscopical picture of buccal mucosa in the olive leaf group at day 14 . The mucosal surface was totally reepithelialized with hyperkeratinisation and hyperplasia, the subepithelia show decreased cellularity of fibrous tissue [H\&E stain $\times 100$ for $(A)$ and $\times 400(B)]$.

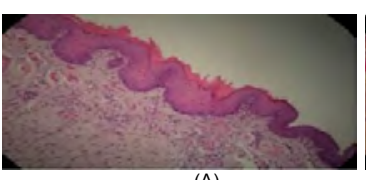

(A)

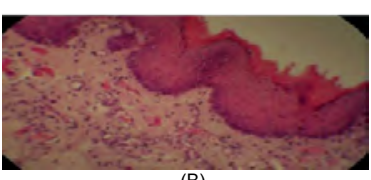

Figure 22: The histological picture of mucosa in benzydamine $\mathrm{HCl}$ groups at day 14 , revealing stratified squamous epithelium covered by thick layer of keratin (hyperkeratinisation and hyperplasia), the submucosa show normal aspects of fibrous tissue [H\&E stain $\times 100$ for $(A)$ and $\times 400$ for $(B)]$. 
Citation: Ahmed KM, Talabani N, Altaei T (2013) Olive Leaf Extract as a New Topical Management for Oral Mucositis Following Chemotherapy: A Microbiological Examination, Experimental Animal Study and Clinical Trial. Pharmaceut Anal Acta 4: 269. doi: 10.4172/2153-2435.1000269

Page 8 of 18

hyperplasia. The subepithelia were more organized with decreased cellularity of fibrous tissue (Figure 21).

Benzydamine $\mathrm{HCl}$ group: In the treated groups with benzydamine $\mathrm{HCl}$, complete healing was observed and the histologic findings were similar to that seen in the olive leaf treated group (Figure 22).

\section{The clinical study}

Patient characterization: Fifty-four patients (26 males and 28 females) out of 62 completed the clinical trial and were included in this part of the study. Characteristics of these patients are as shown in Table 2. The major type of tumour was colorectal cancer (15 cases) followed by ALL (11 cases) and AML (9 cases). The most frequent type of antineoplastic drug groups was 5-fluruouracil, Oxaloplatin and Avastin followed by Methotrexate, Vincristin, Cychlophosphamide, Adriamycine, and then Daunorubicin, Cytosar as shown in Table 3.

Oral mucositis: The mean OMAS mucositis scores at different days are as shown in Table 3. This score was low in the tested drugs at day one and increased gradually till day 8 . At day 15 of the chemotherapy, the mean mucositis score declined. Relatively lower mean value was recorded in patients using olive leaf, followed by benzydamine $\mathrm{HCl}$ and the higher mean value of OMAS score was recorded in the placebo group. These changes in OMAS mucositis score were statistically

\begin{tabular}{|c|c|c|}
\hline Variables & Frequency & Percent \\
\hline \multicolumn{3}{|l|}{ Gender } \\
\hline Male & 26 & 48.1 \\
\hline Female & 28 & 51.9 \\
\hline \multicolumn{3}{|l|}{ Types of tumor } \\
\hline AML & 9 & 16.7 \\
\hline ALL & 11 & 20.4 \\
\hline Ca.Breast & 2 & 3.7 \\
\hline Burkitt's lymphoma & 2 & 3.7 \\
\hline Colorectal carcinoma & 15 & 27.8 \\
\hline $\mathrm{HL}$ & 3 & 5.6 \\
\hline $\mathrm{NHL}$ & 2 & 3.7 \\
\hline Wilm'stumour & 2 & 3.7 \\
\hline Neuroblastoma & 1 & 1.9 \\
\hline PNET & 1 & 1.9 \\
\hline Osteosarcoma & 5 & 9.3 \\
\hline Multiple Myeloma & 1 & 1.9 \\
\hline \multicolumn{3}{|l|}{ Drug groups } \\
\hline $\begin{array}{l}\text { Adriamycine ,Bleomycin, } \\
\text { DecarbazineVinblastin }\end{array}$ & 2 & 3.7 \\
\hline Etoposide, Ifosfamide, Mesna & 5 & 9.3 \\
\hline Daunorubicin, Cytosar & 6 & 11.1 \\
\hline Methotrexate, Vincristion, Adriamycine & 2 & 3.7 \\
\hline $\begin{array}{l}\text { Daunorubicin, Methotrexate,Cychlophosphamide, } \\
\text { Cytosar }\end{array}$ & 4 & 7.4 \\
\hline Methotrexate, Cytosar, L-asparginase & 1 & 1.9 \\
\hline Daunorubicine, Etoposide, Ifosfamide, Decarbazine, & 4 & 7.4 \\
\hline DoxorubicineCytosar, Vincristin, L-asparginase & 3 & 5.6 \\
\hline $\begin{array}{l}\text { Adriamycine ,Bleomycin, } \\
\text { Decarbazine, Vincristin }\end{array}$ & 1 & 1.9 \\
\hline $\begin{array}{l}\text { Daunorubicin, Vincristin, } \\
\text { L-asparginase, Pridinisolone }\end{array}$ & 1 & 1.9 \\
\hline Methotrexate ,Cychlophosphamide, 5-fluruouracil & 2 & 3.7 \\
\hline 5-fluruouracil, Oxaloplatin, Avastin & 15 & 27.8 \\
\hline $\begin{array}{l}\text { Methotrexate, Vincristin, Cychlophosphamide, } \\
\text { AdriamycineVinblastin, cisplatin, decarbazin, interferon }\end{array}$ & 7 & 13.0 \\
\hline Total & 54 & $100 \%$ \\
\hline
\end{tabular}

Table 2: Patient characteristics, type of tumor and drug groups.

\begin{tabular}{|l|l|c|c|c|c|}
\hline \multirow{2}{*}{ Variables } & Tested drugs & \multicolumn{3}{|c|}{ Times (days) Mean } & \multirow{2}{*}{ P value } \\
\cline { 3 - 5 } & & $\mathbf{1}$ & $\mathbf{8}$ & $\mathbf{1 5}$ & \\
\hline OMAS & BenzydamineHCl & 0.06 & 0.23 & 0.09 & \\
\hline & Olive leaf & 0.03 & 0.05 & 0.02 & 0.000 \\
\hline & Placebo & 0.09 & 0.77 & 0.39 & \\
\hline
\end{tabular}

${ }^{*} \mathrm{P}$ value statistically highly significant between OMAS and tested drugs

Table 3: The mean OMAS mucositis score for the tested drugs at different times.

\begin{tabular}{|l|c|c|c|}
\hline \multirow{2}{*}{ Drugs } & \multicolumn{3}{|c|}{ Time (Days) } \\
& $\mathbf{1}$ & $\mathbf{8}$ & $\mathbf{1 5}$ \\
\cline { 2 - 4 } & ${ }^{* * *} 0.06 \pm 0.18$ & ${ }^{* *} 0.23 \pm 0.37$ & ${ }^{*} 0.09 \pm 0.18$ \\
\hline BenzydamineHCl & $0.09 \pm 0.17$ & $0.77 \pm 0.43$ & $0.39 \pm 0.29$ \\
\hline Placebo & ${ }^{*} 0.06 \pm 0.18$ & ${ }^{* *} 0.23 \pm 0.37$ & ${ }^{*} 0.09 \pm 0.18$ \\
\hline Olive leaf & $0.03 \pm 0.10$ & $0.05 \pm 0.12$ & $0.02 \pm 0.10$ \\
\hline Olive leaf & ${ }^{*} 0.03 \pm 0.10$ & ${ }^{* *} 0.05 \pm 0.12$ & ${ }^{* *} 0.02 \pm 0.10$ \\
\hline Placebo & $0.09 \pm 0.17$ & $0.77 \pm 0.43$ & $0.39 \pm 0.29$ \\
\hline
\end{tabular}

${ }^{*} P$ value $\leq 0.05$

${ }^{* *} P$ value $\leq 0.01$

*** $P$ value $>0.05$

Table 4: The mean OMAS mucositis score for the tested drugs using post hoc test.

\begin{tabular}{|l|l|l|l|l|}
\hline \multirow{2}{*}{$\begin{array}{l}\text { WHO grading at } \\
\text { different times }\end{array}$} & \multicolumn{3}{|c|}{ Tested drugs } & P Value \\
\cline { 2 - 4 } & $\begin{array}{l}\text { BenzydamineHCI } \\
\text { N (\%) }\end{array}$ & $\begin{array}{l}\text { Olive leaf } \\
\text { N (\%) }\end{array}$ & $\begin{array}{l}\text { Placebo } \\
\text { N (\%) }\end{array}$ & \\
\hline Day 1 & $48(35.8)$ & $47(35.1)$ & $39(29.1)$ & \multirow{2}{*}{0.159} \\
\hline Grade 0 & $4(17.4)$ & $6(26.1)$ & $13(56.5)$ & \\
\hline Grade 1 & $2(40.0)$ & $1(20.0)$ & $2(40.0)$ & \\
\hline Grade 2 & & & & \multirow{2}{*}{0.000} \\
\hline Day 8 & $33(38.8)$ & $44(51.8)$ & $8(9.4)$ & \\
\hline Grade 0 & $9(45.0)$ & $8(40.0)$ & $3(15.0)$ & \\
\hline Grade 1 & $8(25.0)$ & $2(6.3)$ & $22(68.8)$ & \\
\hline Grade 2 & $4(19.0)$ & $0(.0)$ & $17(81.0)$ & \\
\hline Grade 3 & $0(.0)$ & $0(.0)$ & $4(100.0)$ & \\
\hline Grade 4 & & & & \\
\hline Days 15 & $41(41.0)$ & $50(50.0)$ & $9(9.0)$ & \multirow{2}{*}{0.000} \\
\hline Grade 0 & $9(25.7)$ & $3(8.6)$ & $23(65.7)$ & \\
\hline Grade 1 & $4(19.0)$ & $1(4.8)$ & $16(76.2)$ & \\
\hline Grade 2 & $0(.0)$ & $0(.0)$ & $6(100.0)$ & \\
\hline Grade 3 & & &
\end{tabular}

The bold font shows the significant $P$ value

Table 5: The WHO grades for the tested drugs at different times.

significant. Post hoc analysis with Bonferroni correction showed that the OMAS value at the time of olive leaf application was significantly lower than the other tested drugs (Table 4).

The oral mucositis grades of the present study according to WHO grading system are shown in Table 5. At day one of the treatment, majority of the patients treated with the three tested drugs showed grade 0 , while at day 8 the WHO grade 0 was more in olive leaf group than benzydamine and placebo group. Grade 2, 3 and 4 were more frequent in the placebo group than the olive leaf and benzydamine $\mathrm{HCl}$ group. At day 15 the grade 0 was more frequent in the olive leaf and benzydamine $\mathrm{HCl}$ group, while grades 2 and 3 were most commonly seen in the placebo group. The Kruskall-Wallis test showed that the oral mucositis grade was significantly different at day 8 due to the type of drugs. At day 15, the difference in oral mucositis grades between olive leaf and benzydamine $\mathrm{HCl}$ drugs was insignificant. However, both drugs showed lower oral mucositis grades than the placebo group; the difference was statistically significant (Table 6). 
Citation: Ahmed KM, Talabani N, Altaei T (2013) Olive Leaf Extract as a New Topical Management for Oral Mucositis Following Chemotherapy: A Microbiological Examination, Experimental Animal Study and Clinical Trial. Pharmaceut Anal Acta 4: 269. doi: 10.4172/2153-2435.1000269

Page 9 of 18

\begin{tabular}{|c|c|c|c|c|c|c|c|}
\hline \multirow{2}{*}{$\begin{array}{l}\text { Times } \\
\text { (Days) }\end{array}$} & \multirow{2}{*}{$\begin{array}{l}\text { Tested drugs } \\
\text { groups }\end{array}$} & \multicolumn{5}{|c|}{ Who grading } & \multirow[t]{2}{*}{ PValue } \\
\hline & & $\begin{array}{l}0 \\
\mathrm{~N}(\%)\end{array}$ & $\begin{array}{l}1 \\
\mathrm{~N}(\%)\end{array}$ & 2 & $\begin{array}{l}3 \\
\mathrm{~N}\end{array}$ & $\begin{array}{l}4 \\
N(\%)\end{array}$ & \\
\hline \multirow[t]{6}{*}{1} & BenzydamineHCl & $48(55.2)$ & $4(23.5)$ & $2(50.0)$ & & & 0.051 \\
\hline & Placebo & $39(44.8)$ & $13(76.5)$ & $2(50.0)$ & & & \\
\hline & BenzydamineHCl & $48(50.5)$ & $4(40.0)$ & $2(66.7)$ & & & 0.692 \\
\hline & Olive leaf & $47(49.5)$ & $6(60.0)$ & $1(33.3)$ & & & \\
\hline & Olive leaf & $47(54.7)$ & $6(31.6)$ & $1(33.3)$ & & & 0.161 \\
\hline & Placebo & $39(45.3)$ & $13(68.4)$ & $2(66.7)$ & & & \\
\hline \multirow[t]{6}{*}{8} & Benzydamine $\mathrm{HCl}$ & $33(80.5)$ & $9(75.0)$ & $8(26.7)$ & $4(19.0)$ & $0(0.0)$ & 0.000 \\
\hline & Placebo & 8 (19.5) & $3(25.0)$ & 22 (73.3) & $17(81.0)$ & $4(100.0)$ & \\
\hline & BenzydamineHCl & 33 (42.9) & $9(52.9)$ & $8(80.0)$ & $4(100.0)$ & & 0.026 \\
\hline & Olive leaf & $44(57.1)$ & $8(47.1)$ & $2(20.0)$ & $0(0.0)$ & & \\
\hline & Olive leaf & $44(84.6)$ & $8(72.7)$ & $2(8.3)$ & $0(0.0)$ & $0(0.0)$ & 0.00 \\
\hline & Placebo & $8(15.4)$ & $3(27.3)$ & 22 (91.7) & $17(100.0)$ & $4(100.0)$ & \\
\hline \multirow[t]{6}{*}{15} & BenzydamineHCl & $41(82.0)$ & $9(28.1)$ & $4(20.0)$ & $0(0.0)$ & & 0.000 \\
\hline & Placebo & $9(18.0)$ & $23(71.9)$ & $16(80.0)$ & $6(100.0)$ & & \\
\hline & BenzydamineHCl & $41(45.1)$ & $9(75.0)$ & $4(80.0)$ & & & 0.053 \\
\hline & Olive leaf & $50(54.9)$ & $3(25.0)$ & $1(20.0)$ & & & \\
\hline & Olive leaf & $50(84.7)$ & $3(11.5)$ & $1(5.9)$ & $0(0.0)$ & & 0.000 \\
\hline & Placebo & $9(15.3)$ & $23(88.5)$ & 16 (94.1) & $6(100.0)$ & & \\
\hline
\end{tabular}

The bold font shows the significant $P$ value

Table 6: The WHO grades for the tested drugs by using Kruskall-Wallis test.

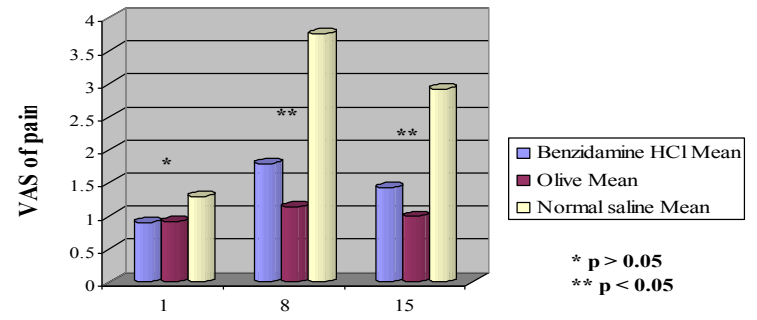

Figure 23: The mean VAS of pain for the tested drugs at different times.

Oral symptoms (pain, difficulty in swallowing and feeding) in the oral mucositis patients: The mean value of VAS for pain is shown in Figure 23. A significant difference in oral symptoms for pain was found between the tested drugs at day 8 and 15. The mean value of VAS in the placebo group increased significantly at day 8 with a further slight increased at day 15 . The mean value of pain experienced by the patients in benzydamine $\mathrm{HCl}$ group was higher at day 8 and 15 than the olive leaf group patients.

The mean value of VAS for difficulty in swallowing is shown in Figure 24. Significant differences existed between groups. As for pain, the placebo group showed increased mean value of difficulty in swallowing at day 8 which slightly increased on day 15 . The mean value of difficulty in swallowing in the benzydamine $\mathrm{HCl}$ group was higher than in the olive leaf group at day 8 and 15 .

For eating function or the pattern of feeding, no significant difference was found between the tested drugs groups at day 1 , while at day 8 and 15 it was noticed that the patients of placebo group found difficulties in eating and chewing normal food, whereas patients in the Benzydamine HCL and olive leaf group expressed less difficulties (Table 7). The Kruskall-Wallis test showed that the feeding pattern was significantly different by the type of the drugs at day 8 and 15 , respectively (Table 8 ).
The clinical picture of patients treated with benzydamine $\mathrm{HCl}$ and olive leaf extract are shown in Figures 25-32.

\section{The microbiological study}

Patient characterization: Thirty patients (20 males and 10 females) were included in this part of the study; characteristics of these patients are as shown in Table 9. The major type of tumour was ALL (9 cases)

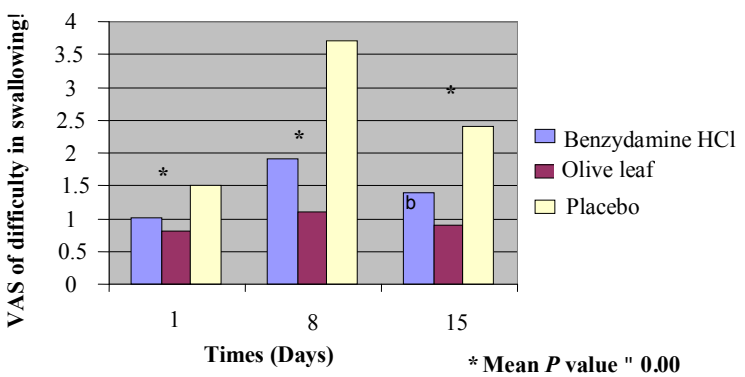

Figure 24: The mean value of VAS for difficulty in swallowing at different times for the tested drugs.

\begin{tabular}{|c|c|c|c|c|}
\hline \multirow{2}{*}{$\begin{array}{l}\text { Eating function at } \\
\text { different times }\end{array}$} & \multicolumn{3}{|c|}{ Tested drugs } & \multirow[t]{2}{*}{$P$ Value } \\
\hline & $\begin{array}{c}\text { Benzydamine } \mathrm{HCl} \\
\mathrm{N}(\%)\end{array}$ & $\begin{array}{l}\text { Olive leaf } \\
\quad \mathrm{N}(\%)\end{array}$ & $\begin{array}{l}\text { Placebo } \\
\text { N (\%) }\end{array}$ & \\
\hline \multicolumn{5}{|l|}{ Day 1} \\
\hline Normal & $49(33.8)$ & $51(35.2)$ & $45(31.0)$ & \multirow[t]{2}{*}{0.159} \\
\hline Soft food only & $5(29.4)$ & $3(17.6)$ & $9(52.9)$ & \\
\hline \multicolumn{5}{|l|}{ Days 8} \\
\hline Normal & $35(38.0)$ & 49 (53.3) & $8(8.7)$ & 0.000 \\
\hline Soft food only & $11(30.6)$ & $5(13.9)$ & $20(55.6)$ & \\
\hline Liquid only & $8(25.8)$ & $0(.0)$ & $23(74.2)$ & \\
\hline No foods or liquids & $0 .(0)$ & $0(.0)$ & $3(100.0)$ & \\
\hline \multicolumn{5}{|l|}{ Days 15} \\
\hline Normal & $42(38.2)$ & $51(46.4)$ & $17(15.5)$ & 0.000 \\
\hline Soft food only & $9(21.4)$ & $3(7.1)$ & $30(71.4)$ & \\
\hline Liquid only & $3(30.0)$ & $0(0)$ & $7(70.0)$ & \\
\hline
\end{tabular}

Table 7: The pattern of feeding between the tested drugs at different times.

\begin{tabular}{|c|c|c|c|c|c|c|}
\hline \multirow{2}{*}{$\begin{array}{l}\text { Times } \\
\text { (Days) }\end{array}$} & \multirow[t]{2}{*}{ Tested drugs } & \multicolumn{4}{|c|}{ Eating function } & \multirow[t]{2}{*}{ P Value } \\
\hline & & $\begin{array}{c}\text { Normal } \\
\text { N (\%) }\end{array}$ & $\begin{array}{c}\text { Soft food } \\
\text { only } \\
N(\%)\end{array}$ & $\begin{array}{l}\text { Liquid } \\
\text { only } \\
N(\%)\end{array}$ & $\begin{array}{c}\text { No foods } \\
\text { or liquids } \\
\mathrm{N}(\%)\end{array}$ & \\
\hline \multirow[t]{6}{*}{1} & BenzydamineHCl & $49(49.0)$ & $5(62.5)$ & & & \multirow[t]{2}{*}{0.462} \\
\hline & Olive leaf & $51(51.0)$ & $3(37.5)$ & & & \\
\hline & Olive leaf & $51(53.1)$ & $3(25.0)$ & & & \multirow[t]{2}{*}{0.066} \\
\hline & Placebo & $45(46.9)$ & $9(75.0)$ & & & \\
\hline & BenzydamineHCl & $49(52.1)$ & $5(35.7)$ & & & \multirow[t]{2}{*}{0.252} \\
\hline & Placebo & $45(47.9)$ & $9(64.3)$ & & & \\
\hline \multirow[t]{6}{*}{8} & BenzydamineHCl & $35(41.7)$ & $11(68.8)$ & $8(100.0)$ & & \multirow[t]{2}{*}{0.002} \\
\hline & Olive leaf & $49(58.3)$ & $5(31.2)$ & $0(0.0)$ & & \\
\hline & Olive leaf & $49(86.0)$ & $5(20.0)$ & $0(0.0)$ & $0(0.0)$ & \multirow[t]{2}{*}{0.000} \\
\hline & Placebo & $8(14.0)$ & $20(80.0)$ & $23(100.0)$ & $3(100.0)$ & \\
\hline & BenzydamineHCl & $35(81.4)$ & $11(35.5)$ & $8(25.8)$ & $0(0.0)$ & \multirow[t]{2}{*}{0.000} \\
\hline & Placebo & $8(18.6)$ & $20(64.5)$ & $23(74.2)$ & $3(100.0)$ & \\
\hline \multirow[t]{6}{*}{15} & BenzydamineHCl & $42(45.2)$ & $9(75.0)$ & $3(100.0)$ & & \multirow[t]{2}{*}{0.032} \\
\hline & Olive leaf & $51(54.8)$ & $3(25.0)$ & $0(0.0)$ & & \\
\hline & Olive leaf & $51(75.0)$ & $3(9.1)$ & $0(0.0)$ & & \multirow[t]{2}{*}{0.000} \\
\hline & Placebo & $17(25.0)$ & $30(90.9)$ & $7(100.0)$ & & \\
\hline & BenzydamineHCl & $42(71.2)$ & $9(23.1)$ & $3(30.0)$ & & \multirow[t]{2}{*}{0.000} \\
\hline & Placebo & $17(28.8)$ & $30(76.9)$ & $7(70.0)$ & & \\
\hline
\end{tabular}

Table 8: The feeding pattern for the tested drugs by using Kruskall-Wallis test. 
Citation: Ahmed KM, Talabani N, Altaei T (2013) Olive Leaf Extract as a New Topical Management for Oral Mucositis Following Chemotherapy: A Microbiological Examination, Experimental Animal Study and Clinical Trial. Pharmaceut Anal Acta 4: 269. doi: 10.4172/2153-2435.1000269

Page 10 of 18

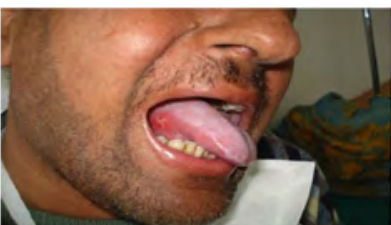

(A)

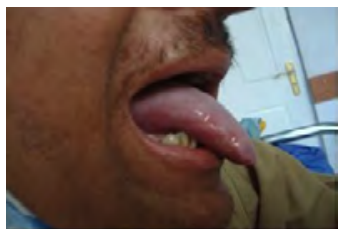

(B)
Figure 25: Thirty five year old male treated with intensive chemotherapy for AML (A) shows an ulcer measuring more than $2 \mathrm{~cm}$ in diameter in the right lateral border of the tongue; $(B)$ shows the same ulcer healed after 4 days of olive leaf extract application.

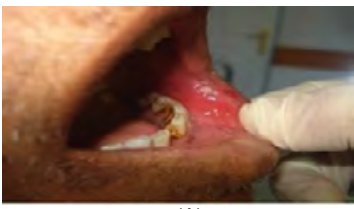

(A)

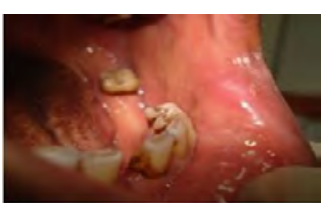

(B)
Figure 26: Fifty four year old male treated with intensive chemotherapy for AML (A) shows an ulcer in the left side of the lower lip; (B) represents the healed ulcer after 4 days of applying olive leaf extract.

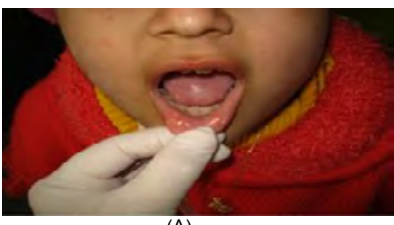

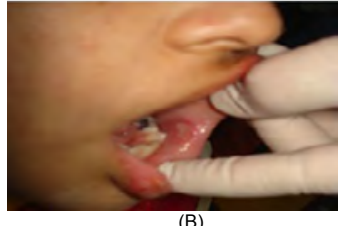

Figure 27: An eight year old female received chemotherapy for ALL, $(A, B)$ shows ulcers less than $1 \mathrm{~cm}$ in diameter in the inner aspect of the lower lip and cheek.
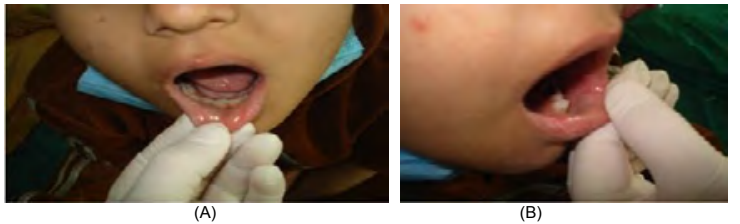

Figure 28: (A) The same patient after application of olive leaf for 3 days. (B) Complete healing of the ulcers.

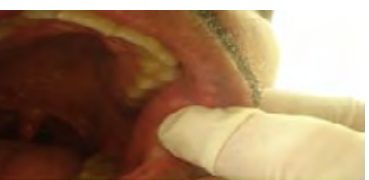

(A)

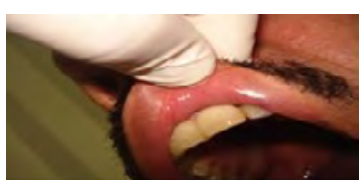

(B)
Figure 29: Thirty five year old male with colorectal cancer received intensive chemotherapy (A) shows ulcer measured more than $1 \mathrm{~cm}$ in diameter in the left side of the upper lip, (B) shows the healed ulcer after 3 days of applying olive leaf.

followed by AML and NHL (4 cases each) and the most frequent type of drug groups was Etoposide, Ifosfamide, Mesna; Daunorubicin, Cytosar; Daunorubicin, Cytosar, Vincristin, L-asparginase, details are as shown in Table 9.
Oral mucositis assessment: The mean OMAS mucositis scores are as shown in Figure 33. Before administering chemotherapy, the mean value of OMAS mucositis score was 0.205 . One week after starting chemotherapy, oral mucositis developed gradually with a steep increase observed after two-weeks. Three weeks after chemotherapy, the OMAS mucositis score decreased. These changes in mucositis score in four weeks intervals were statistically significant $(\mathrm{P}<0.001)$.

Oral mucositis were also evaluated using WHO mucositis score; the

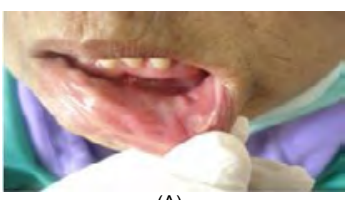

(A)

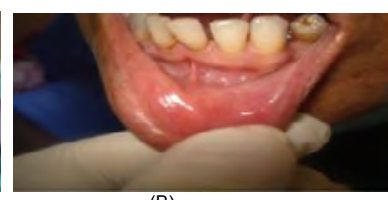

Figure 30: Thirty seven year old female with $\mathrm{NHL}$ received intensive chemotherapy (A) shows an ulcer in the left side of the lower lip (B) represents the healed ulcer after 6 days of applying benzydamine $\mathrm{HCl}$ medication.

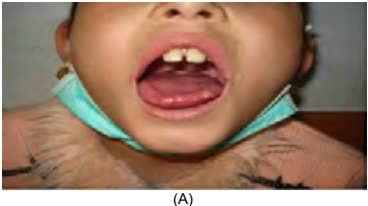

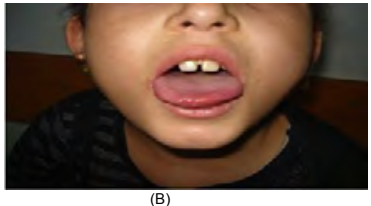

(B)
Figure 31: Ten-year-old female received chemotherapy for ALL (A) shows multiple ulcers in the left side of ventral surface of the tongue (B) shows the healed ulcer after 4 days of applying benzydamine $\mathrm{HCl}$.

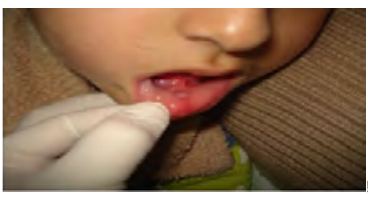

(A)

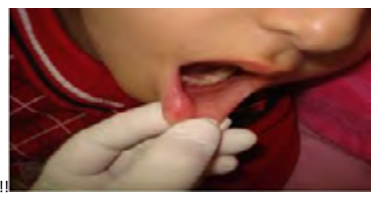

Figure 32: Six-year-old male with ALL received intensive chemotherapy (A) shows ulcer in the inner aspect of the lower lip, (B) represents the healed ulcer after 5 days of applying of benzydamine $\mathrm{HCl}$

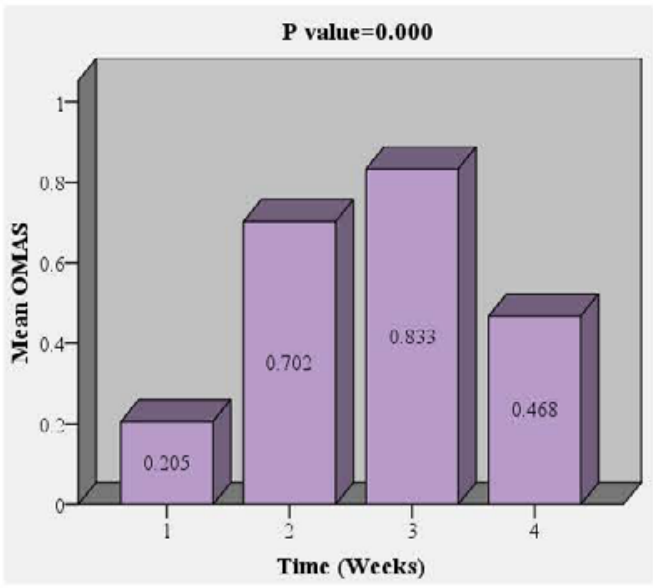

Figure 33: The mean OMAS mucositis score in 30 patients with intensive chemotherapy in four weeks intervals. 
Citation: Ahmed KM, Talabani N, Altaei T (2013) Olive Leaf Extract as a New Topical Management for Oral Mucositis Following Chemotherapy: A Microbiological Examination, Experimental Animal Study and Clinical Trial. Pharmaceut Anal Acta 4: 269. doi: 10.4172/2153-2435.1000269

Page 11 of 18

\begin{tabular}{|c|c|c|}
\hline Variables & Frequency & Percent \\
\hline \multicolumn{3}{|l|}{ Gender } \\
\hline Male & 20 & 66.7 \\
\hline Female & 10 & 33.3 \\
\hline \multicolumn{3}{|l|}{ Type of tumor } \\
\hline AML & 4 & 13.3 \\
\hline ALL & 9 & 30.0 \\
\hline Ca.breast & 2 & 6.7 \\
\hline Burkitt's lymphoma & 2 & 6.7 \\
\hline Colorectal carcinoma & 1 & 3.3 \\
\hline $\mathrm{HL}$ & 3 & 10.0 \\
\hline $\mathrm{NHL}$ & 4 & 13.3 \\
\hline Wilm's tumor & 1 & 3.3 \\
\hline Neuroblastoma & 1 & 3.3 \\
\hline PNET & 2 & 6.7 \\
\hline Osteosarcoma & 1 & 3.3 \\
\hline \multicolumn{3}{|l|}{ Drug groups } \\
\hline Adriamycine ,Bleomycin, Decarbazine, Vinblastin & 1 & 3.3 \\
\hline Etoposide, Ifosfamide, Mesna & 4 & 13.3 \\
\hline Daunorubicin, Cytosar & 4 & 13.3 \\
\hline Methotrexate, Vincristion, Adriamycine & 1 & 3.3 \\
\hline $\begin{array}{l}\text { Daunorubicin, Methotrexate, Cychlophosphamide, } \\
\text { Cytosar }\end{array}$ & 2 & 6.7 \\
\hline Methotrexate, Cytosar, L-asparginase & 1 & 3.3 \\
\hline Etoposide, Ifosfamide, Decarbazine, Doxorubicine & 1 & 3.3 \\
\hline Daunorubicin, Cytosar, Vincristin, L-asparginase & 4 & 13.3 \\
\hline Bleomycin, Decarbazine, Vinblastin & 1 & 3.3 \\
\hline Vincristin ,Cychlophosphamide, Doxorubicine & 2 & 6.7 \\
\hline Adriamycine ,Bleomycin, Decarbazine, Vincristin & 1 & 3.3 \\
\hline Daunorubicin, Vincristin, L-asparginase, Pridinisolone & 2 & 6.7 \\
\hline Methotrexate ,Cychlophosphamide, 5-fluruouracil & 2 & 6.7 \\
\hline 5-fluruouracil, Oxaloplatin, Avastin & 1 & 3.3 \\
\hline $\begin{array}{l}\text { Methotrexate, Vincristin, Cychlophosphamide, } \\
\text { Adriamycine }\end{array}$ & 1 & 3.3 \\
\hline $\begin{array}{l}\text { Cytosar, Vincristin, L-asparginase, } \\
\text { Cychlophosphamide }\end{array}$ & 1 & 3.3 \\
\hline $\begin{array}{l}\text { Vincristin, L-asparginase, Cychlophosphamide, } \\
\text { Predinisolone }\end{array}$ & 1 & 3.3 \\
\hline Total & 30 & 100 \\
\hline
\end{tabular}

Table 9: Patient characteristics, type of tumor and drug groups.

\begin{tabular}{|c|c|c|c|c|c|c|}
\hline \multirow{2}{*}{$\begin{array}{l}\text { WHO } \\
\text { Grades }\end{array}$} & \multicolumn{4}{|c|}{ Time (weeks) } & \multirow[t]{2}{*}{$P$ value } & \multirow[t]{2}{*}{ Total No. } \\
\hline & $\begin{array}{c}1 \\
N(\%)\end{array}$ & $\begin{array}{c}2 \\
N(\%)\end{array}$ & $\begin{array}{c}3 \\
N(\%)\end{array}$ & $\begin{array}{c}4 \\
N(\%)\end{array}$ & & \\
\hline Grade 0 & $19(63.3)$ & $6(20.0)$ & $2(6.9)$ & $9(33.3)$ & \multirow[t]{5}{*}{0.000} & 26 \\
\hline Grade 1 & $10(33.3)$ & $10(33.3)$ & $9(31.0)$ & $12(44.4)$ & & 41 \\
\hline Grade 2 & $1(3.3)$ & $9(30.0)$ & $11(37.9)$ & $5(18.5)$ & & 26 \\
\hline Grade 3 & $0(0.0)$ & $4(13.3)$ & $7(24.1)$ & $1(3.7)$ & & 12 \\
\hline Grade 4 & $0(0.0)$ & $1(3.3)$ & $0(0.0)$ & $0(0.0)$ & & 1 \\
\hline Total (\%) & 100 & 100 & 100 & 100 & & \\
\hline No. & 27 & 29 & 30 & 30 & & 116 \\
\hline
\end{tabular}

Table 10: The WHO mucositis score before and three weeks after taking chemotherapy.

results are as shown in Table 10. The frequency (percentage) of grade 2 , grade 3 and grade 4 oral mucositis score increased after one week of starting chemotherapy. After three weeks of chemotherapy (at week 4) the frequency (percentage) of grade 2 , grade 3 and grade 4 oral mucositis score decreased. Kruskal-Wallis test showed that the difference among the grading stages and the time intervals was statistically significant $(\mathrm{P}$ value $<0.001)$.

\section{Microorganisms}

The total bacterial count: The mean bacterial count during the four weeks of the analysis is as shown in Figure 34. The total bacterial count before starting chemotherapy was low, but after one week of taking chemotherapy the total bacterial count increased and reached its highest level. Two weeks after, the mean bacterial count decreased. There was insignificant difference between the mean bacterial count during the studied period ( $\mathrm{P}$ value $>0.05$ ).

\section{The relationship between bacterial count and time intervals after administration of chemotherapy}

The relationship between bacterial colonization and the time (days or weeks) in the studied cases was relatively low $\left(\mathrm{R}^{2}=0.022\right)$ (that is, time plays a weak insignificant role in changing the pattern of bacterial colonization) as displayed in Figure 35.

\section{The relationship between bacterial colonization and mucositis severity}

The relationship between the increase in bacterial count and the course of oral mucositis is as shown in Figure 36. The mean bacterial count was high after one week of chemotherapy with mucositis severity reaching its peak after two weeks of chemotherapy indicating a reversal relationship between the increasing level of mucositis and bacterial colonization. No significant correlations existed between OMAS score and the mean bacterial count at the studied period $(r=0.792, r=0.626$,

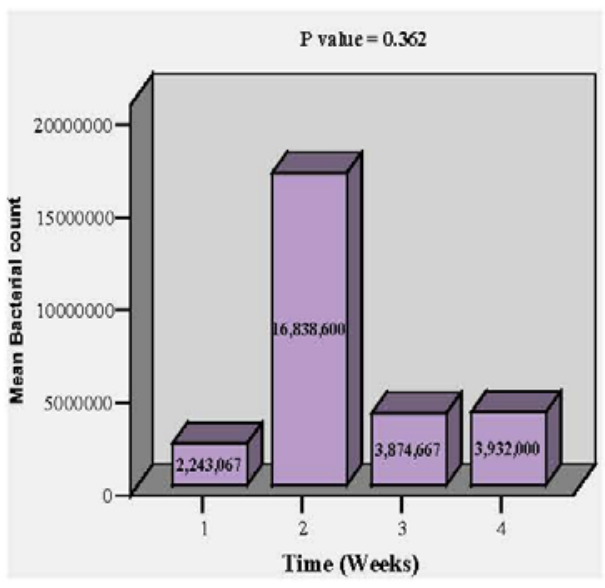

Figure 34: The mean bacterial count in four weeks.

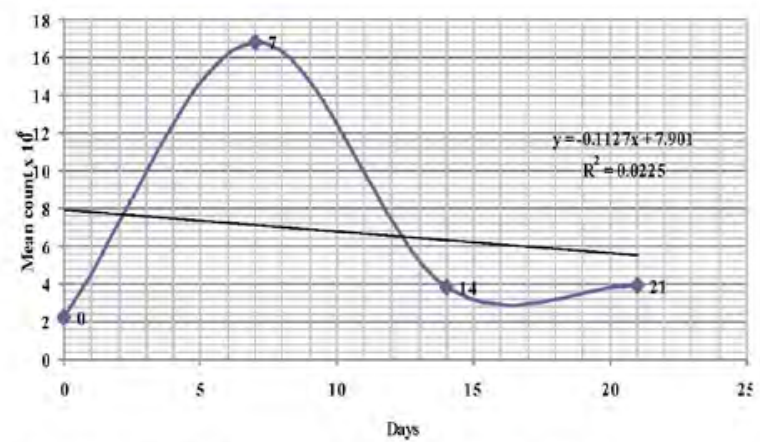

Figure 35: The relationship between the mean bacterial count and time. 


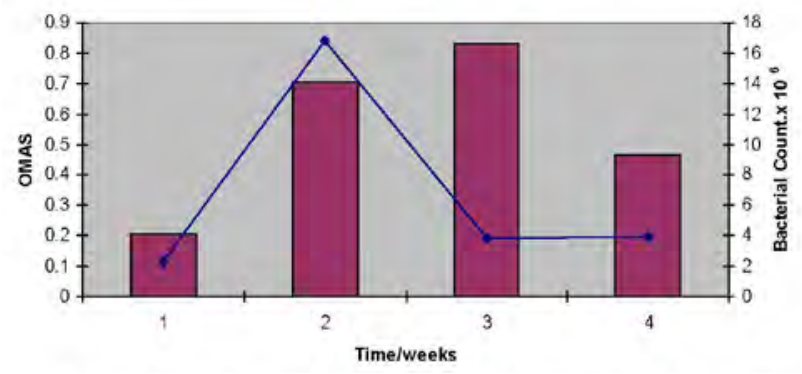

Figure 36: The relationship between bacterial count and OMAS score at the studied time. The bars represent OMAS and the line represents the bacterial count.

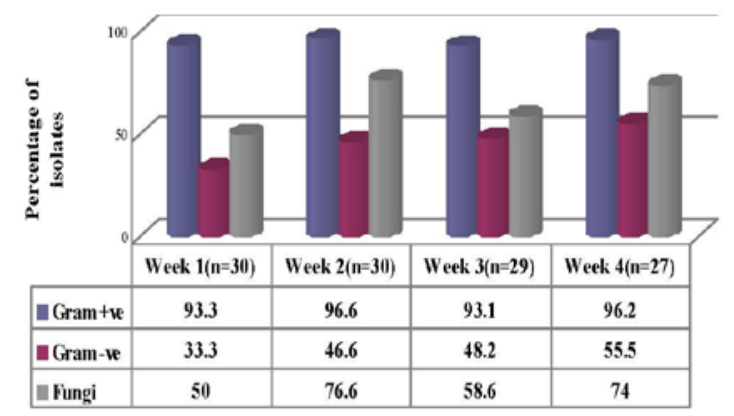

Time/Weeks

Figure 37: The percentage of Gram +ve, Gram -ve bacteria and fungi in cancer patients at four weeks intervals.

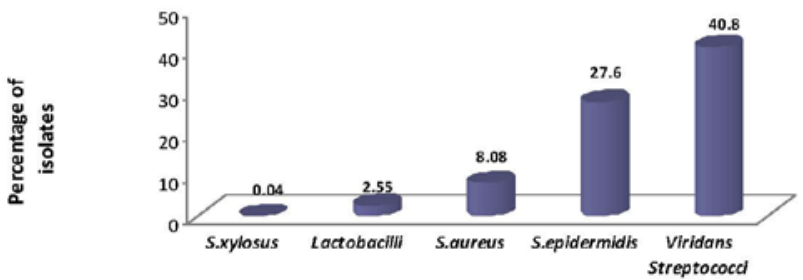

Gram positive bacteria

Figure 38: The total percentage of Gram + ve bacteria identified in studied patients at four weeks intervals.

$\mathrm{r}=0.433$ and $\mathrm{r}=0.596$, respectively for $\mathrm{wk} 1, \mathrm{wk} 2, \mathrm{wk} 3$ and $\mathrm{wk} 4)$.

\section{Isolation and identification of bacteria and fungi}

Isolates of bacteria and fungi per week before and after administration of chemotherapy is as shown in Figure 37. Majority of patients showed evidence growth for Gram-positive bacteria $(93.3,96.6,93.1$ and $96.2 \%$, respectively for week 1, 2, 3 and 4), which increased gradually after the administration of chemotherapeutic drugs (33.3, 46.6, 48.2 and 55.5\%, respectively for week 1, 2, 3 and 4). However, the pattern of fungi growth varies in the different weeks; details are as shown in Figure 37. Regarding the effect of time (weeks) on the percentage isolation rate of Gram positive, Gram-negative bacteria and fungi, it was noticed that time had no significant effect on the percentage isolation rate $(\mathrm{p}=0.393)$.
The following microorganisms were identified based on culture characteristics, biochemical properties and API systems. The percentages of the different species of Gram +ve and Gram -ve bacteria are as shown in Figures 38 and 39. Viridans streptococci was the major identified bacteria (Gram +ve and Gram -ve) followed by S. epidermidis as shown in Figure 38. The highest percentage of Gram -ve bacteria was Pseudomonas auroginosa followed by K. oxytoca (Figure 39).

The total percentage of identified fungi is shown in Figure 40; Candida albicans was the most commonly identified fungal isolate followed by Trichosporon mucoides.

\section{The antimicrobial activity of olive leaf and benzydamine $\mathrm{HCl}$}

Determinations of MIC, MBC and MFC of olive leaf and benzydamine $\mathrm{HCl}$ against different bacterial and fungal isolates are shown in Table 11. Interestingly, the MBC of olive leaf extract showed only bactericidal effects, whereas the $\mathrm{MBC}$ of benzydamine $\mathrm{HCl}$ showed bactericidal and bacteriostatic effects.

The MIC of benzydamine $\mathrm{HCl}$ : Benzydamine $\mathrm{HCl}$ showed

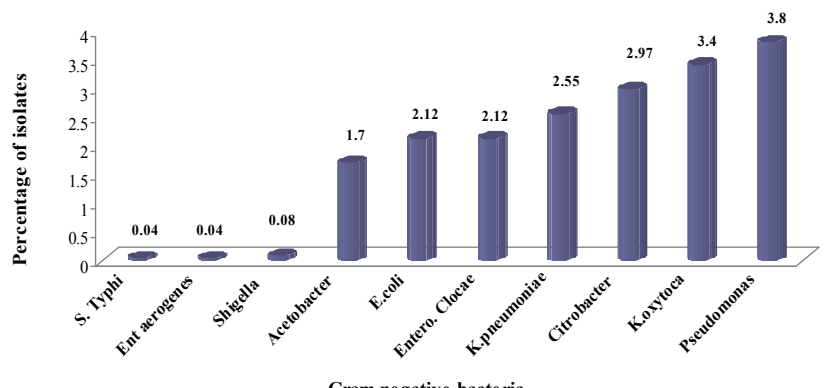

Gram negative bacteria

Figure 39: The total percentage of Gram -ve bacteria identified in studied patients at four weeks intervals.

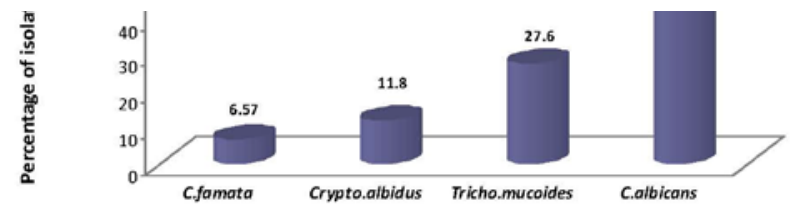

Fungi

Figure 40: The total percentage of fungi identified in studied patients at four weeks intervals.

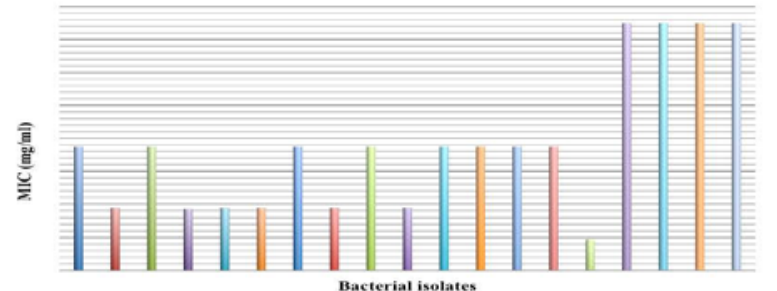

Figure 41: The minimal inhibitory concentration of benzydamine $\mathrm{HCl}$ against different microorganisms. 


\begin{tabular}{|c|c|c|c|c|c|}
\hline \multirow{2}{*}{$\begin{array}{l}\text { Micro } \\
\text { organisms }\end{array}$} & \multirow{2}{*}{$\begin{array}{l}\text { Bacterial } \\
\text { isolates }\end{array}$} & \multicolumn{2}{|c|}{ BenzydamineHCl } & \multicolumn{2}{|c|}{ Olive leaf } \\
\hline & & $\begin{array}{c}\text { MIC } \\
(\mathrm{mg} / \mathrm{ml})\end{array}$ & MBC & $\begin{array}{c}\text { MIC } \\
(\mathrm{mg} / \mathrm{ml})\end{array}$ & MBC \\
\hline \multirow{5}{*}{$\begin{array}{l}\text { Gram positive } \\
\text { bacteria }\end{array}$} & S. xylosus & 0.75 & Bacteriostatic & 166.5 & Bactericidal \\
\hline & S. aureus & 0.375 & Bacteriostatic & 83.25 & Bactericidal \\
\hline & S. epidermidis & 0.75 & Bactericidal & 166.5 & Bactericidal \\
\hline & Viridans Strep. & 0.375 & Bactericidal & 83.25 & Bactericidal \\
\hline & Lactobacilli & 0.375 & Bactericidal & 166.5 & Bactericidal \\
\hline \multirow{10}{*}{$\begin{array}{l}\text { Gram } \\
\text { negative } \\
\text { bacteria }\end{array}$} & S. typhi & 0.375 & Bactericidal & 41.625 & Bactericidal \\
\hline & Pseudomonas & 0.75 & Bacteriostatic & 166.5 & Bactericidal \\
\hline & K. oxytoca & 0.375 & Bactericidal & 166.5 & Bactericidal \\
\hline & Citrobacter & 0.75 & Bacteriostatic & 166.5 & Bactericidal \\
\hline & Shigella & 0.375 & Bactericidal & 83.25 & Bactericidal \\
\hline & E. coli & 0.75 & Bacteriostatic & 83.25 & Bactericidal \\
\hline & Entero. clocae & 0.75 & Bacteriostatic & 83.25 & Bactericidal \\
\hline & Ent. aerogenes & 0.75 & Bactericidal & 83.25 & Bactericidal \\
\hline & K. pneumoniae & 0.75 & Bacteriostatic & 83.25 & Bactericidal \\
\hline & Acinetobacter & 0.1875 & Bactericidal & 83.25 & Bactericidal \\
\hline \multirow[t]{4}{*}{ Fungi } & C. albicans & 1.5 & Fungicidal & 166.5 & Fungicidal \\
\hline & C. famata & 1.5 & Fungicidal & 166.5 & Fungicidal \\
\hline & Crypto.albidus & 1.5 & Fungicidal & 166.5 & Fungicidal \\
\hline & Tricho.mucoides & 1.5 & Fungicidal & 166.5 & Fungicidal \\
\hline
\end{tabular}

Table 11: The MIC and MBC of olive leaf and benzydamine $\mathrm{HCl}$ against different isolated microorganisms.

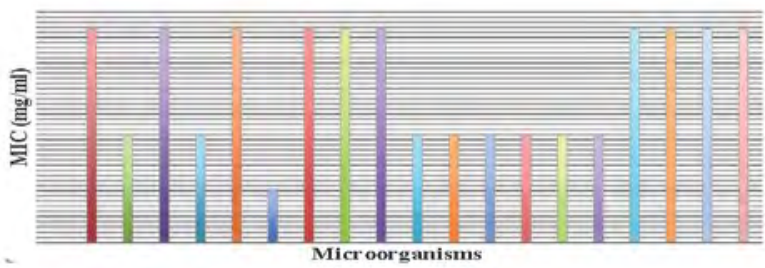

Figure 42: The minimal inhibitory concentration of olive leaf extract against different microorganisms.

different antimicrobial activity against the identified microorganisms with lowest MIC value against Acinetobacter calcoaceticus $(0.1875 \mathrm{mg} /$ $\mathrm{ml}$ ) (Figure 41). No significant differences were found between MIC of Gram-positive and Gram-negative bacteria $(\mathrm{p}=0.64)$.

The MIC of olive leaf extract: Olive leaf extract had different antimicrobial effects on the identified microorganisms with lowest MIC value against $S$. typhi $(41.625 \mathrm{mg} / \mathrm{ml})$ (Figure 42). There were no significant differences between MIC of Gram-positive and Gramnegative bacteria $(\mathrm{p}=0.25)$.

\section{Discussion}

\section{Oral mucositis}

Oral mucositis induced by chemotherapy or radiotherapy in cancer patients is a frequently occurring toxicity. Apart from its painful side effect, it restricts oral function such as speech, chewing and swallowing [1]. Accordingly, it increases the suffering of patients who are already under the pressure of cancer and the traumatic effects of chemotherapy or radiotherapy. No decisive or definite local treatment for oral mucositis is so far available.

Descriptive and mechanistic researches conducted over the past decade have resulted in a better understanding of the pathogenesis and occurrence of these undesirable side effects. The risk of oral mucositis development is multifactorial, predictable, quantifiable and largely genetically determined. Our ability to develop effective risk prediction will be an important step in the development of customized patient interventions. According to Sonis [44], normal cells and tumor cells do not respond in the same way to cytotoxic therapy; therefore pharmacologic toxicity prevention at the mechanistic level is a realistic goal without jeopardizing tumor response to treatment.

To date, despite the current understanding of the complex development of oral mucositis in cancer patients, no interventions are available for absolute prevention or treatment of oral mucositis. Interventions that target only one specific process as part of the mucositis pathobiology process have been reported to be largely ineffective [1]. Prevention and treatment of oral mucositis should be directed toward multiple biological targets of the mucositis process either by an intervention with multiple mechanism effects or combination of interventions. Until now, there is a general approval of the use of palifermin as drug of choice (with certain limitations) for the prevention and treatment of mucositis [44-47]; however, this drug is given through intravenous route not as topical application.

In the present study, an alternative effective intervention for oral mucositis with less limitations and easy application was investigated. This local treatment was olive leaf extract, which is a safe natural herbal product with no known toxicity or lethality [26,48]. Topical olive leaf extract was used to treat recurrent aphthous ulceration and its effect was compared with the effect of topical dexamethasone elixir [49]. These authors concluded that both medications reduce the size of the ulcers and also decreased the pain; no significant difference was detected. Thus, olive leaf extract was thoroughly investigated in this research through microbiological examination, experimental animal studies and clinical trial.

\section{The microbiological study}

The oral cavity is one of the most complex environments in the body; it contains various bacteria, fungi, protozoa and virus [44,50-52].

The role played by oral flora in the aetiology of oral mucositis is a matter of speculation; previous hypothesis suggested that increase in bacterial numbers drive oral mucositis. However, the new pathogenesis model of oral mucositis suggests a possible role of oral microflora in intensifying the ulcerative phase of oral mucositis rather than an etiologic factor [47,44]. Moreover, Donnelly et al. and Mosca et al. $[3,53]$. hypothesized that the general role of microflora in oral mucositis is not well characterized but reduction in the microbial load of the oral cavity appears to have some benefit in the treatment of oral mucositis as well as decreasing its severity [3,53]. On the other hand, Napeñas et al. [54], who proposed a negative result to support the use of antimicrobial agents for the reduction of oral mucositis, reveal that the antimicrobial agents studied targeted the wrong bacterial species or the role played by micoorganisms in oral mucositis was over estimated [54].

Vokurka et al. and Kumar Madan et al. [55,56] emphasized the use of antimicrobial mouth wash as treatment against oral bacterial and fungal infections and that it is widely used in the nursing care and management of oral mucositis. On the other hand, extensive growth of microorganisms in the oral cavity of immunosuppressed patients posses a considerable risk for systemic infections. Some investigators argue that, between 10.5 and $41 \%$ of bone marrow transplant patients with septicaemia have an oral focus as port of entry [55-58].

In the present study, the oral washing method (for taking samples) was used according to the technique described by Stokman et al. and 
Spijkervet et al. $[29,59]$ who suggested that gargling method is superior to swab method for the following reasons: gargling permits sampling of the entire oropharyngeal cavity including tonsillar crypt and possibly inaccessible area; allows the use of a defined volume of saline and letting the subject gargle for a specified period of time [29,59]. The mean concentrations of microorganisms received from gargle samples were higher than the mean concentrations obtained by swab technique. Additionally, the tested material in this study was constructed as mouth rinse, which may affect the entire oral environment.

To enhance the sensitivity of saline gargle method, we made dilution in Brain Heart Infusion broth; this enrichment step permitted detection of very low concentration of microorganisms as justified by Stokman et al. and Spijkervet et al. [29,59]. The quantitative changes in the number of oral bacteria with higher level after one week of administration of chemotherapy may be due to the compromised host health condition during the administration of antineoplastic drugs. Both the systemic and oral mucosal immunity was affected which could have led to changes in the oral environment including a decrease in saliva volume and modification of saliva constituents. Moreover, hospital inpatients may acquire pathogenic bacteria through nosocomial means. Another factor may be due to reduced oral hygiene in such patients due to the side effect of the cytotoxic drugs. However, bacteria count decreases after two weeks (day 14 and 21), which may be due to recuperation of the normal immune response. When comparing the results to other studies, it was notice that the quantitative changes in oral bacteria during chemotherapy varies with no changes in bacterial count [60], either decreased bacterial count [61] or increased bacterial count [62] Decreased and increased of bacteria count was reported by Sixou et al. [63] which is consistent with our results.

It has been found that qualitative changes in oral flora during chemotherapy presented an increase in Gram -ve organisms during ulceration phase of oral mucositis [9,44,54]. In this study, it was found that there was a gradual increase in Gram -ve organism after chemotherapy administration, which confirmed the findings of the above-mentioned authors. However, this increase of Gram -ve organisms does not explain the shifting of oral flora from Gram +ve to Gram -ve; Viridans streptococci was the predominant microorganisms. Another reason for oral floral changes in these patients may be due to antibiotic intake before and during chemotherapy, which may alter the qualitative, and quantitative oral microflora profile. Gram -ve organisms may be actively involved in the process of oral mucositis development.

Gram +ve Streptococci and Staphylococci organisms increase the risk for occurrence of oral mucositis due to the difficulties in controlling their proliferation and spread as reported by studies $[9,57,64]$. Moreover the Viridans streptococci may use lesions of the oral mucosa to penetrate the general circulation and cause infection in these immunosuppressed patients $[57,63,65]$. According to Stokman et al. and Napeñas et al. [29,54], Gram -ve Enterobacteriacea and Pseudomonas sp. microorganisms may intensify the inflammatory process and exacerbate or promote ulcer formation through the release of endotoxin which interacts with macrophages to induce the production of inflammatory cytokines (TNF- $\alpha$, IL-6, and IL-1 $\beta$ ) $[29,54]$.

The role of fungi (candida) in the aetiology of mucositis has been a subject of speculation for some time and remained marginally controversial. Candidiasis is a common finding among patients receiving head and neck radiation or myeloabaltive chemotherapy; therefore, it is not unexpected that these organisms can be identified in patients with mucositis as a coincident condition [44]. It has been reported that candidiasis account for $75 \%$ of oral infections in carcinoma patients during chemotherapy $[52,66]$. In the present study, the fungal growth was observed in a large number of patients $(76.6 \%)$ after one week of chemotherapy.

An interesting finding in this part of the study was the association of total bacterial count with OMAS mucositis score; the peak mucositis score occurred after two weeks of administration of chemotherapy at which time the bacterial count decreased. Relatively similar observation was also reported by many other investigators $[3,54,55,66,67]$. The OMAS score in the present study increased after three weeks of chemotherapy administration and was associated with further decrease in bacterial count. This finding contradicted the observation of Sonis (2009) [44] who reported that the peak bacterial loads coincided with peak mucositis scores at week three in experimental animals [44].

The MBC of olive leaf extract and benzydamine $\mathrm{HCl}$ was different; benzydamine $\mathrm{HCl}$ showed bactericidal and bacteriostatic activity, while olive leaf showed only bactericidal activity. This is important because the use of bactericidal medication is preferred over bacteriostatic medication since the latter needs sufficient duration to allow cellular and humoral defence mechanisms to eradicate the bacteria [68].

The comparison of MIC of olive leaf extract and benzydamine $\mathrm{HCl}$ was difficult to displayed in a single graph since the therapeutic dose was $333 \mathrm{mg} / \mathrm{ml}$ in olive leaf and $1.5 \mathrm{mg} / \mathrm{ml}$ in benzydamine $\mathrm{HCl}$, therefore each product was studied separately for MIC value. Both products exerted broad-spectrum activity against the isolated microorganisms. According to Epstein et al., Sonis and Silverman Jr. [69-71], benzydamine $\mathrm{HCl}$ showed antimicrobial activity, which is consistent with our observation.

Generally, olive leaf extract showed higher antimicrobial activity on the isolated microorganisms in the tube dilution method in comparison with benzydamine HCL. The olive leaf has been long known to exert broad-spectrum activity against a wide range of bacteria [18], virus [19], fungi and mycoplasma [20,21], which confirms our observation. Moreover, the antimicrobial action of olive leaf may prove useful in cases where prolonged use of antibiotic encourages development of opportunistic infection as declared by Markin et al. [21].

The MIC value of benzydamine $\mathrm{HCl}$ and olive leaf that indicates insignificant difference in antibacterial activity against Gram +ve and Gram -ve bacteria, is also important since Gram -ve bacteria have cell wall impermeable to lipohilic solutes while Gram +ve bacteria are susceptible because it has only an outer peptiodoglycan layer which is not an effective permeability barrier [72].

Moreover, the olive leaf secondary metabolite was active against Gram +ve and Gram -ve bacteria, which is rather a unique result, since most plant's secondary metabolites show more potent activity against Gram +ve than Gram -ve bacteria [73].

\section{The animal study}

Current therapy for oral mucositis induced by chemotherapy is largely palliative. The major current treatment for oral mucositis in clinical setting is to provide pain relief with local anaesthetics, or coating the oral mucosa and to locally administer bactericidal or antiinflammatory agents such as benzydamine $\mathrm{HCl}$ [41].

In the present study, in order to evaluate the potential effectiveness of local application of olive leaf and benzydamine $\mathrm{HCl}$, an animal model was designed for oral mucositis induced by 5 -FU based on the 
model described by Sonis et al. [38]. In this experimental animal model, it was necessary to produce a superficial scratching of the mucosa to stimulate a functional trauma. Several techniques of mucosal scratching have been described including the use of needles $[4,38]$ and low speed burs [74]. In the present study, superficial scratching of the cheek mucosa was performed by orthodontic wire that allows scratching without causing epithelial disruption $[15,39,41]$. The chemotherapyinduced mucositis in animals has been widely used in several studies $[4,15,38,39,40,41,75]$. The use of this protocol allowed inducing oral mucositis lesions in the animals in a similar manner as those reported in humans with development lesions, 3-5 days after the commencement of the chemotherapeutic regimen.

Therapeutic benzydamine $\mathrm{HCl}$ has been investigated as a preventive and treatment option for oral mucositis in humans $[69,70,71,76,77]$ while the therapeutic effect of olive leaf on oral mucositis has not been tried.

The body weight of rats in all examined groups decreased significantly, reaching lowest value in day 7-8 of the study. Similar observation was reported by Sonis et al., Clarke et al. and Mitsuhashi et al. $[38,39,41]$. These authors suggested a link between low immune competence and mucositis severity with weight loss.

After day 8 of the experiments, the body weight of the rats in the treated and control groups started increasing almost to their normal weight by day 12 . However, animal weight gain was significantly higher in the treated groups in comparison to the control group. This may be explained on the basis that healing of the oral mucositis was faster in the treated groups, which allowed the animals to consume their food and water properly.

Regarding the development of oral mucositis along the experimental periods, it was observed that the ulcerated lesions were milder in the treated groups than the control group which indicates that the severity of the lesions was reduced by benzydamine $\mathrm{HCl}$ and olive leaf therapy.

It is known that chemotherapeutic agents interfere with the DNA synthesis mainly in cells that have high mitosis rate and rapid proliferation such as the oral epithelial cells. In effect, the mucosal injury is a complex process involves increase in the rate of epithelial cell apoptosis and necrosis with decreased renewal of mucosal epithelium. Mucosal injury is exacerbated by local bacterial colonization (of oral flora), which results in the penetration of the cell wall product into the submucosa, amplifying the inflammatory damage to the surface epithelium leading to further damage. Early healing requires healthy fibroblasts to lay down extra cellular matrix including collagen fiber [78]. Furthermore, inflammatory cell infiltration was mild in the treated groups and severe in the control group. These factors collectively influenced the results and revealed the anti-inflammatory capacity of olive leaf and benzydamine $\mathrm{HCl}$ to stimulate fibrous and epithelial proliferation (huperplasia and hyperkeratinisation) as well as decrease inflammatory cell infiltration leading to faster healing of the induced mucosal lesions.

\section{The clinical study}

This part of the study was performed to assess the effect of olive leaf extract in reducing the incidence and severity of oral mucositis in comparison with benzydamine $\mathrm{HCl}$ and placebo (normal saline). The design of the study was in the form of crossover double blind placebo controlled study similar to the method described by Cheng et al., Verdi et al. and Awidi et al. $[76,79,80]$. The selection of this design was based on the fact that it was extremely difficult to control and standardizes all therapy and patient specific variables in a single oncology centre. Another reason for selection of the design was the practical difficulty of obtaining sufficient number of patients in a single centre that meets all the inclusion criteria in the study time period. Generally all patients included in the present study were those receiving intensive courses of chemotherapy. About $85 \%$ of these patients are at risk of developing oral mucositis [55,81-84].

Moreover, the complex mucositis pathogenesis that was reported in 2004 by Sonis [10] and his colleagues and further support by other investigators demonstrated that mucositis is not solely a clinical event $[44,47,85,86]$. The changes occur in the submucosal endothelium rather than the epithelium which means that the condition starts as a subclinical event. These subclinical changes were confirmed by the presence of microscopic damage before macroscopic injury become visible $[47,86]$. Important evidence in the absence of clinically visible lesion is that mucositis risk existed and increased in each course of chemotherapy cumulatively, therefore cancer patients experienced mucositis clinically or subclinically.

The evaluation of the tested local drugs was performed weekly for two weeks following the suggestion of Shabanloei et al. [87] who found that any interference with mucositis should be made within the first two weeks of chemotherapy in order to reduce the risk [87].

The effect of the tested drugs on oral mucositis: According to Madan et al. [56] an ideal oral rinse for patients with mucositis should reduce the oral microflora, promote reepithelization of soft tissue lesions, normalize the $\mathrm{pH}$ of oral fluids, have an acceptable taste and be non toxic [56]; the three different mouthwashes that was tested in this part of the study meets these criteria.

Benzydamine $\mathrm{HCl} 0.15 \%$ oral rinse was showed to be safe, well tolerated and effective for prophylactic treatment of radiation induced oral mucositis [69]. Benzydamine $\mathrm{HCl}$ also proved to be effective in children under chemotherapy [76]. Benzydamine $\mathrm{HCl}$ was acceptable and well tolerated by children over the age of 6 years receiving chemotherapy for hematological and solid tumour [77]. More recent study by Kazemian et al. [88] demonstrated that Benzydamine $\mathrm{HCl}$ oral rinse was effective as a prophylactic treatment for radiation induced oral mucositis in head and neck tumour [88].

Olive leaf extract has not been reported (in any English written literature) to be used for topical treatment of oral mucositis. However, the only article that referred to olive leaf extract was Atai et al. [49], reported that a locally prepared olive leaf extract was found to be as effective as dexamethason elixir for treatment of aphthous ulcers.

The placebo mouth rinse was composed of normal saline. Saline solution mouthwash are safe and economical and have been used in cancer patient as gargle to cleanse wounds, reduces swelling and may decrease pain [56]. In the present study, normal saline mouthwash was not found to be as effective as olive leaf and benzydamine $\mathrm{HCl}$.

Comparison between olive leaf and benzydamine $\mathrm{HCl}$ as local treatment for oral mucositis: Olive leaf extract was more effective in reducing the incidence and/or the severity of oral mucositis when compared with benzydamine $\mathrm{HCl}$. Benzydamine $\mathrm{HCl}$ was found to be effective when applied 4-8 times daily before and during cancer therapy [69]; the frequency of application of benzydamine $\mathrm{HCl}$ was 2-3 times more than that of olive leaf extract (3-4 times daily).

Olive leaf extract showed better effect against isolated oral microorganisms especially fungi as compared to benzydamine when tube dilution method was employed. Another important property of the 
tested drugs was its anti-inflammatory action. The anti-inflammatory effect of both benzydamine and olive leaf was reported in other studies $[17,69-71,89]$. Histological examination of the tissues in the animal part of this study revealed that both drugs decreased inflammatory cell infiltration that may explain their mode of action as anti-inflammatory agent.

Another interesting feature of olive leaf is that it inhibits platelet aggregation in vitro [25]. Sonis, Wang et al. [44,90] and showed that inhibited platelet aggregation reduced mucositis because plateletactivating factor increases correspondingly with the severity of oral mucositis [44,90]. On the other hand, Sonis et al. [10] suggested that the inhibition of platelet aggregation is associated with reduced mucosal toxicity and confirmed the possible role of vascular endothelium and platelets in the pathogenesis of mucositis [10]. The levels of plateletactivating factor in mixed saliva or in gingival crevicular fluid and tissues significantly increased during oral inflammatory conditions such as periodontitis and mucositis [91].

Effects of the tested drugs on subjective symptoms of oral mucositis (pain, difficulty in swallowing and eating function): The subjective symptoms such as oral mucosal pain, difficulty in swallowing and eating function relating to oral mucositis have been studied by many investigators $[6,84,92,93-96]$. In fact, these subjective measures were regarded as important tools in the assessment of patient's complication relating to oral mucositis with objective measure by OMAS mucositis score [31]

Oral mucosal pain resulting from mucositis is a frequent finding in patients receiving chemotherapy or radiotherapy; in fact the severity of oral mucositis was associated with overall increased intensity of oral pain. Topical drugs such as topical anaesthetics, analgesics and coating drugs have been used in cancer patients to relieve mucosal pain.

In the present part of the study, it has been noticed that the mean value of oral pain in olive leaf group was less than the values of pain in the benzydamine and placebo groups. This depends on the value of oral mucositis (OMAS and WHO), which was low in the olive leaf group than the other two groups. This finding is consistent with the observation of oral mucositis as the principle aetiology for oral pain in patients undergoing cancer treatment $[85,92,97]$. The mean value of pain in benzydamine groups was lower than the values in the placebo groups which confirms the results of Epstein et al. [69], who showed that treatment with benzydamine produced topical analgesic effect in radiation induced mucositis. However, the value of pain in placebo groups in our patients was not more than $4 \mathrm{~mm}$ in VAS, which may be due to the effect of systemic analgesics that were prescribed routinely during cancer therapy throughout the study period.

Dysphagia (or difficulty in swallowing) is the single most intense and distressing problem for patients with oral mucositis. Borbasi et al. [98] revealed that one of the most frustrating aspects of oral mucositis is that it induces swallowing difficulties and eating unpalatable [98]. Control of dysphagia therefore is a chief concern in the management of oral mucositis. It was noted that difficulty in swallowing in the olive leaf group lessen. Benzydamine group was better than the placebo group, which is due to lesser severity of mucositis in these groups than the placebo group.

The functional impairment of eating (or feeding pattern) also showed a direct advantage of olive leaf over benzydamine and placebo groups. This result is also important since in more severe cases of oral mucositis; unrelenting pain and subsequent inability to eat and drink trigger the onset of secondary malnutrition and dehydration. This will create an even more complex situation where potential interruptions in treatments and invasive methods of nutritional correction can lead to a marked increase in co-morbidity [99].

\section{Conclusions}

In accordance with the established objectives and the results obtained, it can be concluded that:

- The use of olive leaf was more effective in alleviating oral mucositis in comparison to benzydamine $\mathrm{HCl}$ and placebo.

- The expression of oral pain, difficulty in swallowing and eating function lessen in the olive leaf treated groups over benzydamine $\mathrm{HCl}$ and placebo groups.

- In the animal part of the study, both olive leaf and benzydamine $\mathrm{HCl}$ reduced the size of ulcer area in the buccal mucosa of rats with complete healing at day 10 ; the control groups of rats showed persistent ulcer throughout the experimental period.

- No clear evidence existed for the role of oral flora in developing oral mucositis.

Further investigations on a larger scale including both radiotherapy and chemotherapy patients with different treatment protocols is required for confirmation of the obtained results.

\section{References}

1. Stokman MA, Spijkervet FK, Boezen HM, Schouten JP, Roodenburg JL, et al (2006) Preventive intervention possibilities in radiotherapy- and chemotherapyinduced oral mucositis: results of meta-analyses. J Dent Res 85: 690-700.

2. Clarkson JE, Worthington HV, Eden TOB (2007) Interventions for treating oral mucositis for patients with cancer receiving treatment. Cochrane Database of Syst Rev : CD001973.

3. Donnelly JP, Bellm LA, Epstein JB, Sonis ST, Symonds RP (2003) Antimicrobial therapy to prevent or treat oral mucositis. Lancet Infect Dis 3: 405-412.

4. Loury D, Embree JR, Steinberg DA, Sonis ST, Fiddes JC (1999) Effect of local application of the antimicrobial peptide IB-367 on the incidence and severity of oral mucositis in hamsters. Oral Surg Oral Med Oral Pathol Oral Radiol Endod 87: $544-551$

5. Naidu MU, Ramana GV, Rani PU, Mohan IK, Suman A, et al. (2004) Chemotherapy-induced and/or radiation therapy-induced oral mucositiscomplicating the treatment of cancer. Neoplasia 6: 423-431.

6. Nes AG, Posso MB (2005) Patients with moderate chemotherapy-induced mucositis: pain therapy using low intensity lasers. Int Nurs Rev 52: 68-72.

7. Peterson DE (1992) Oral toxicity of chemotherapeutic agents. Semin Oncol 19: 478-491.

8. Trotti A, Bellm LA, Epstein JB, Frame D, Fuchs HJ, et al. (2003) Mucositis incidence, severity and associated outcomes in patients with head and neck cancer receiving radiotherapy with or without chemotherapy: a systematic literature review. Radiother Oncol 66: 253-262.

9. Filicko J, Lazarus HM, Flomenberg N (2003) Mucosal injury in patients undergoing hematopoietic progenitor cell transplantation: new approaches to prophylaxis and treatment. Bone Marrow Transplant 31: 1-10.

10. Sonis ST, Elting LS, Keefe D, Peterson D E, Schubert M, et al. (2004) Perspectives on cancer therapy-induced mucosal injury: pathogenesis, measurement, epidemiology, and consequences for patients. Cancer 100 : 1995-2025.

11. Scully C, Sonis S, Diz PD (2006) Oral mucositis. Oral Dis 12: 229-241.

12. Wardley AM, Jayson GC, Swindell R, Morgenstern GR, Chang J, et al. (2000) Prospective evaluation of oral mucositis in patients receiving myeloablative conditioning regimens and haemopoietic progenitor rescue. $\mathrm{Br} \mathrm{J}$ Haematol 110: 292-299.

13. Barasch A, Peterson DE (2003) Risk factors for ulcerative oral mucositis in cancer patients: unanswered questions. Oral Oncol 39: 91-100. 
Citation: Ahmed KM, Talabani N, Altaei T (2013) Olive Leaf Extract as a New Topical Management for Oral Mucositis Following Chemotherapy: A Microbiological Examination, Experimental Animal Study and Clinical Trial. Pharmaceut Anal Acta 4: 269. doi: 10.4172/2153-2435.1000269

14. Cheng KK, Goggins WB, Lee VW, Thompson DR (2008) Risk factors for oral mucositis in children undergoing chemotherapy: a matched case-control study. Oral Oncol 44: 1019-1025.

15. Sacono NT, Costa CA, Bagnato VS, Abreu-e-Lima FC (2008) Light-emitting diode therapy in chemotherapy-induced mucositis. Lasers Surg Med 40: 625-633.

16. Visioli F, Galli C (2002) Biological properties of olive oil phytochemicals. Crit Rev Food Sci Nutr 42: 209-221

17. de la Puerta R, Martínez-Domínguez E, Ruíz-Gutiérrez V (2000) Effect of minor components of virgin olive oil on topical antiinflammatory assays. Z Naturforsch C 55: 814-819.

18. Walker M (1996) Olive leaf extract. The new oral treatment to counteract most types of pathological organisms.

19. Lee-Huang S, Huang PL, Zhang D, Lee JW, Bao J, et al. (2007) Discovery of small-molecule HIV-1 fusion and integrase inhibitors oleuropein and hydroxytyrosol. Biochem. Biophys Res Commun 354: 872-884.

20. Aziz NH, Farag SE, Mousa LA, Abo-Zaid MA (1998) Comparative antibacteria and antifungal effects of some phenolic compounds. Microbios 93: 43-54.

21. Markin D, Duek L, Berdicevsky I (2003) In vitro antimicrobial activity of olive leaves. Mycoses 46: 132-136.

22. Coni E, Di Benedetto R, Di Pasquale M, Masella R, Modesti D, et al. (2000) Protective effect of oleuropein, an olive oil biophenol, on low density lipoprotein oxidizability in rabbits. Lipids $35: 45-54$.

23. Manna C, Migliardi V, Golino P, Scognamiglio A, Galletti P, et al. (2004) Oleuropein prevents oxidative myocardial injury induced by ischemia and reperfusion. J Nutr Biochem 15: 461-466.

24. Andreadou I, Sigala F, Iliodromitis EK, Papaefthimiou M, Sigalas C, et al. (2007) Acute doxorubicin cardiotoxicity is successfully treated with the phytochemical oleuropein through suppression of oxidative and nitrosative stress. J Mol Cel Cardiol 42: 549-558.

25. Singh I, Mok M, Christensen AM, Turner AH, Hawley JA (2008) The effects of polyphenols in olive leaves on platelet function. Nutr Metab Cardiovasc Dis 18: $127-132$

26. Hamdi HK, Castellon R (2005) Oleuropein, a non-toxic olive iridoid, is an antitumor agent and cytoskeleton disruptor. Biochem Biophys Res Commun 334 769-778.

27. Abaza L, Talorete TP, Yamada P, Kurita Y, Zarrouk M, et al. (2007) Induction of growth inhibition and differentiation of human leukemia HL-60 cells by a Tunisian gerboui olive leaf extract. Biosci Biotechnol Biochem 71: 1306-1312.

28. Spijkervet FK, van Saene HK, Panders AK, Vermey A, van Saene JJ, et al (1989) Effect of chlorhexidine rinsing on the oropharyngeal ecology in patients with head and neck cancer who have irradiation mucositis. Oral Surg Oral Med Oral Pathol 67: 154-161.

29. Stokman MA, Spijkervet FK, Burlage FR, Dijkstra PU, Manson WL, et al. (2003) Oral mucositis and selective elimination of oral flora in head and neck cance patients receiving radiotherapy: a double-blind randomised clinical trial. $\mathrm{Br} J$ Cancer 88: 1012-1016.

30. World Health Organization (1979) WHO handbook for reporting results of cancer treatment. Geneva: World Health Organization, Geneva, Switzerland:15-22.

31. Sonis ST, Eilers JP, Epstein JB, LeVeque FG, Liggett WH Jr, et al. (1999) Validation of a new scoring system for the assessment of clinical trial research of oral mucositis induced by radiation or chemotherapy. Mucositis Study Group. Cancer 85: 2103-2113.

32. Holt JG, Noel RK, Peter HAS, James TS, Stanley TW (1994) Bergey's manual of determinative bacteriology. (9th edn). Lippincott William \& Wilkins.

33. Atlas RM, Alfred EB, Lawrence CP (1995) Laboratory manual experimental microbiology. Mosby-year, Inc.

34. Mahon C , Manuselis G (2000) Text book of diagnostic microbiology. (2nd edn), W B Saunders Company.

35. Aneja K R (2003) Experiments in microbiology plant pathology and biotechnology. (4th edn), New age international (p) Ltd., publisher.

36. Morello JA, Granato PA and Mizer HE (2003) Laboratory manual and work book in microbiology, application to patient care. (7th edn), The Mc Graw-Hill componies.
37. National Committee for Clinical Laboratory Standards (2003) Methods for dilution antimicrobial susceptibility tests for bacteria that grow aerobically. (5th edn) Approved Standard M7-A6. NCCLS, Villanova, PA, USA.

38. Sonis ST, Tracey C, Shklar G, Jenson J, Florine D (1990) An animal model fo mucositis induced by cancer chemotherapy. Oral Surg Oral Med Oral Pathol 69: 437-443

39. Clarke J, Edwards B, Srpek L, Regester G (1999) Evaluation of bovine lactoferrin as a topical therapy for chemotherapy-induced mucositis in the golden Syrian hamster. Oral Oncol 35: 197-202.

40. Lima V, Brito GA, Cunha FQ, Rebouças CG, Falcão BA, et al. (2005) Effects of the tumour necrosis factor-alpha inhibitors pentoxifylline and thalidomide in short-term experimental oral mucositis in hamsters. Eur J Oral Sci 113: 210 217.

41. Mitsuhashi H, Suemaru K, Li B, Cui R, Araki H (2006) Evaluation of topical external medicine for 5 -fluorouracil-induced oral mucositis in hamsters. Eur $\mathrm{J}$ Pharmacol 551: 152-155.

42. Fall-Dickson JM, Ramsay ES, Castro K, Patricia Woltz P, Sport C (2007) Oral Mucositis-Related Oropharyngeal Pain and Correlative Tumor Necrosis Factor-a Expression in Adult Oncology Patients Undergoing Hematopoietic Stem Cell Transplantation. Clinical Therapeutics 29: 2547-2561.

43. Collins SL, Edwards J, Moore RA, Smith LA, McQuay HJ (2001) Seeking simple measure of analgesia for mega-trials: is a single global assessment good enough? Pain 91: 189-194.

44. Sonis ST (2009) Mucositis: The impact, biology and therapeutic opportunities of oral mucositis. Oral Oncol 45: 1015-1020.

45. Spielberger R, Stiff $P$, Bensinger W, Gentile T, Weisdorf D, et al. (2004) Palifermin for oral mucositis after intensive therapy for hematologic cancers. N Engl J Med 351: 2590-2598.

46. Blijlevens N, Sonis S (2007) Palifermin (recombinant keratinocyte growth factor-1): a pleiotropic growth factor with multiple biological activities in preventing chemotherapy- and radiotherapy-induced mucositis. Ann Oncol 18 817-826.

47. Sonis ST (2007) Pathobiology of oral mucositis: novel insights and opportunities. J Support Oncol 5: 3-11.

48. Lee-Huang S, Zhang L, Huang PL, Chang Y, Huang PL (2003) Anti-HIV activity of olive leaf extract (OLE) and modulation of host cell gene expression by HIV-1 infection and OLE treatment. Biochem Biophys Res Commun 307: 1029-1037.

49. Atai Z, Ansari M, Torabi N (2007) Efficacy of Olive Leaf Extract in the Treatment of Minor Oral Aphthous Ulcers. American Journal of Infectious Diseases 3: 24 26.

50. Schuster GS (1999) Oral flora and pathogenic organisms. Infect Dis Clin North Am 13: 757-774, v.

51. Könönen E (2000) Development of oral bacterial flora in young children. Ann Med 32: 107-112.

52. Worthington HV, Clarkson JE (2002) Prevention of oral mucositis and ora candidiasis for patients with cancer treated with chemotherapy: cochrane systematic review. J Dent Educ 66: 903-911.

53. Mosca DA, Hurst MA, So W, Viajar BS, Fujii CA, et al. (2000) IB-367, a protegrin peptide with in vitro and in vivo activities against the microflora associated with oral mucositis. Antimicrob Agents Chemother 44: 1803-1808.

54. Napeñas JJ, Brennan MT, Bahrani-Mougeot FK, Fox PC, Lockhart PB (2007) Relationship between mucositis and changes in oral microflora during cance chemotherapy. Oral Surg Oral Med Oral Pathol Oral Radiol Endod 103: 48-59.

55. Vokurka S, Bystrická E, Koza V, Scudlová J, Pavlicová V, et al. (2005) The comparative effects of povidone-iodine and normal saline mouthwashes on ora mucositis in patients after high-dose chemotherapy and APBSCT--results of a randomized multicentre study. Support Care Cancer 13: 554-558.

56. Madan PD, Sequeira PS, Shenoy K, Shetty J (2008) The effect of three mouthwashes on radiation-induced oral mucositis in patients with head and neck malignancies: a randomized control trial. J Cancer Res Ther 4: 3-8.

57. Ruescher TJ, Sodeifi A, Scrivani SJ, Kaban LB, Sonis ST (1998) The impact of mucositis on alpha-hemolytic streptococcal infection in patients undergoing autologous bone marrow transplantation for hematologic malignancies. Cance 82: $2275-2281$. 
Citation: Ahmed KM, Talabani N, Altaei T (2013) Olive Leaf Extract as a New Topical Management for Oral Mucositis Following Chemotherapy: A Microbiological Examination, Experimental Animal Study and Clinical Trial. Pharmaceut Anal Acta 4: 269. doi: 10.4172/2153-2435.1000269

Page 18 of 18

58. Pitten FA, Kiefer T, Buth C, Doelken G, Kramer A (2003) Do cancer patients with chemotherapy-induced leukopenia benefit from an antiseptic chlorhexidinebased oral rinse? A double-blind, block randomized, controlled study. J Hosp Infect 53:283-291.

59. Spijkervet FKL, van Saene HKF, Panders AK, Veramey A (1989c) Colonisation index of the oral cavity: a novel technique for monitoring colonisation defence. Microb Ecol Health Dis; 2:145-151.

60. Lucas VS, Beighton D, Roberts GJ, Challacombe SJ (1997) Changes in the oral streptococcal flora of children undergoing allogeneic bone marrow transplantation. J Infect 35: 135-141.

61. O'Sullivan EA, Duggal MS, Bailey CC, Curzon ME, Hart P (1993) Changes in the oral microflora during cytotoxic chemotherapy in children being treated for acute leukemia. Oral Surg Oral Med Oral Pathol 76: 161-168.

62. Bergmann OJ (1991) Alterations in oral microflora and pathogenesis of acute oral infections during remission-induction therapy in patients with acute myeloid leukaemia. Scand J Infect Dis 23: 355-366.

63. Sixou JL, De Medeiros-Batista O, Gandemer V, Bonnaure-Mallet M (1998) The effect of chemotherapy on the supragingival plaque of pediatric cancer patients. Oral Oncol 34: 476-483.

64. Smith AJ, Jackson MS, Bagg J (2001) The ecology of Staphylococcus species in the oral cavity. J Med Microbiol 50: 940-946.

65. Sugiura Y, Soga Y, Tanimoto I, Kokeguchi S, Nishide S, et al. (2008) Antimicrobia effects of the saliva substitute, Oralbalance, against microorganisms from oral mucosa in the hematopoietic cell transplantation period. Support Care Cancer 16: $421-424$

66. Jensen SB, Mouridsen HT, Bergmann OJ, Reibel J, Brünner N, et al. (2008) Oral mucosal lesions, microbial changes, and taste disturbances induced by adjuvant chemotherapy in breast cancer patients. Oral Surg Oral Med Oral Pathol Oral Radiol Endod 106: 217-226.

67. Bondi E, Baroni C, Prete A, Gatti M, Carrassi A, et al. (1997) Local antimicrobia therapy of oral mucositis in paediatric patients undergoing bone marrow transplantation. Oral Oncol 33: 322-326

68. Levison ME (2004) Pharmacodynamics of antimicrobial drugs. Infect Dis Clin North Am 18: 451-465, vii.

69. Epstein JB, Silverman S Jr, Paggiarino DA, Crockett S, Schubert MM, et al. (2001) Benzydamine $\mathrm{HCl}$ for prophylaxis of radiation-induced oral mucositis: results from a multicenter, randomized, double-blind, placebo-controlled clinical trial. Cancer 92: 875-885.

70. Sonis ST (2004) Oral mucositis in cancer therapy. J Support Oncol 2: 3-8.

71. Silverman Jr S (2007) Diagnosis and Management of Oral Mucositis. J Support Oncol 5: 13-21.

72. Ruttoh EK, Tarus PK, Bii CC, Machocho AK, Karimie LK, et al. (2009) Antibacterial activity of Tabernaemontana stapfiana britten (Apocynaceae) extracts. Afr J Tradit Complement Altern Med 6: 186-194.

73. Bisignano G, Laganà MG, Trombetta $D$, Arena $S$, Nostro $A$, et al. (2001) In vitro antibacterial activity of some aliphatic aldehydes from Olea europaea L. FEMS Microbiol Lett 198: 9-13.

74. Morvan FO, Baroukh B, Ledoux D, Caruelle JP, Barritault D, et al. (2004) An engineered biopolymer prevents mucositis induced by 5 -fluorouracil in hamsters. Am J Pathol 164: 739-746.

75. Sonis ST, Van Vugt AG, Brien JP, Muska AD, Bruskin AM, et al. (1997) Transforming growth factor-beta 3 mediated modulation of cell cycling and attenuation of 5-fluorouracil induced oral mucositis. Oral Oncol 33: 47-54.

76. Cheng KK, Chang AM, Yuen MP (2004) Prevention of oral mucositis in paediatric patients treated with chemotherapy; a randomised crossover trial comparing two protocols of oral care. Eur J Cancer 40: 1208-1216.

77. Cheng KK (2004) Children's acceptance and tolerance of chlorhexidine and benzydamine oral rinses in the treatment of chemotherapy-induced oropharyngeal mucositis. Eur J Oncol Nurs 8: 341-349.

78. Lee SW, Jung KI, Kim YW, Jung HD, Kim HS, et al. (2007) Effect of epiderma growth factor against radiotherapy-induced oral mucositis in rats. Int J Radiat Oncol Biol Phys 67: 1172-1178.

79. Verdi CJ, Garewal HS, Koenig LM, Vaughn B, Burkhead T (1995) A doubleblind, randomized, placebo-controlled, crossover trial of pentoxifylline for the prevention of chemotherapy-induced oral mucositis. Oral Surg Oral Med Oral Pathol Oral Radiol Endod 80: 36-42.

80. Awidi A, Homsi U, Kakail RI, Mubarak A, Hassan A, et al. (2001) Double-blind placebo-controlled cross-over study of oral pilocarpine for the prevention of chemotherapy-induced oral mucositis in adult patients with cancer. Eur $\mathrm{J}$ Cancer 37: 2010-2014

81. Epstein JB, Tsang AH, Warkentin D, Ship JA (2002) The role of salivary function in modulating chemotherapy-induced oropharyngeal mucositis: a review of the literature. Oral Surg Oral Med Oral Pathol Oral Radiol Endod 94: 39-44.

82. McGuire DB (2002) Mucosal tissue injury in cancer therapy. More than muscositis and mouthwash. Cancer Pract 10: 179-191.

83. Sonis ST (2004) The pathobiology of mucositis. Nat Rev Cancer 4: 277-284

84. Blijlevens NM, Donnelly JP, Yakar D, van Die CE, de Witte T (2007) Determining mucosal barrier injury to the oesophagus using CT scan. Support Care Cancer 15: $1105-1108$.

85. Stokman MA, Spijkervet FK, Burlage FR, Roodenburg JL (2005) Clinical effects of flurbiprofen tooth patch on radiation-induced oral mucositis. A pilot study. Support Care Cancer 13: 42-48.

86. Logan RM (2008) Alimentary tract mucositis NF-?B and pro-inflammtory cytokines in the tissues and serum following chemotherapy. A Ph D thesis submitted to school of Dentistry, Faculty of Health Science, University of Adelaide.

87. Shabanloei R, Ahmadi F, Vaez J, Ansarin K, Hajizadehe, et al. (2009) Alloporinol, chamomile and normal saline mouthwashes for the prevention of chemotherapy-induced stomatitis. Journal of Clinical and Diagnostic Research 3: $1537-1542$.

88. Kazemian A, Kamian S, Aghili M, Hashemi FA, Haddad P (2009) Benzydamine for prophylaxis of radiation-induced oral mucositis in head and neck cancers: a double-blind placebo-controlled randomized clinical trial. Eur J Cancer Care (Engl) 18: 174-178.

89. Sironi M, Massimiliano L, Transidico P, Pinza M, Sozzani S, et al. (2000) Differential effect of benzydamine on pro- versus anti-inflammatory cytokine production: lack of inhibition of interleukin-10 and interleukin-1 receptor antagonist. Int J Clin Lab Res 30: 17-19.

90. Wang J, Albertson CM, Zheng H, Fink LM, Herbert JM, et al. (2002) Shortterm inhibition of ADP-induced platelet aggregation by clopidogrel ameliorates radiation-induced toxicity in rat small intestine. Thromb Haemost 87: 122-128.

91. Tsoupras AB, Antonopoulou S, Baltas G, Samiotaki M, Panayotou G, et al (2006) Isolation and identification of hydroxyl-platelet-activating factor from natural sources. Life Sci 79: 1796-1803.

92. Stokman MA, Wachters FM, Koopmans P, Burgerhof JG, Groen HJ, et al (2004) Outcome of local application of amifostine (WR-1065) on epirubicininduced oral mucositis. A phase II study. Anticancer Res 24: 3263-3267.

93. Epstein JB, Epstein JD, Epstein MS, Oien H, Truelove EL (2006) Oral doxepin rinse: the analgesic effect and duration of pain reduction in patients with oral mucositis due to cancer therapy. Anesth Analg 103: 465-470, table of contents.

94. Epstein JB, Epstein JD, Epstein MS, Oien H, Truelove EL (2007) Management of pain in cancer patients with oral mucositis: follow-up of multiple doses of doxepin oral rinse. J Pain Symptom Manage 33: 111-114.

95. Arora H, Pai KM, Maiya A, Vidyasagar MS, Rajeev A (2008) Efficacy of He-Ne Laser in the prevention and treatment of radiotherapy-induced oral mucositis in oral cancer patients. Oral Surg Oral Med Oral Pathol Oral Radiol Endod 105: 180-186, 186.

96. Cheng KK (2007) Oral mucositis, dysfunction, and distress in patients undergoing cancer therapy. J Clin Nurs 16: 2114-2121.

97. Cheng KKF, Molassiotis A, Chang AM, Wai WC, Cheung SS (2001) Evaluation of an oral care protocol intervention in the prevention of chemotherapy-induced oral mucositis in paediatric cancer patients. Eur J Cancer 37: 2056-2063.

98. Borbasi S, Cameron K, Quested B, Olver I, To B, et al. (2002) More than a sore mouth: patients' experience of oral mucositis. Oncol Nurs Forum 29: 1051 1057.

99. Barber C, Powell R, Ellis A, Hewett J (2007) Comparing pain control and ability to eat and drink with standard therapy vs Gelclair: a preliminary, double centre, randomised controlled trial on patients with radiotherapy-induced oral mucositis. Support Care Cancer 15: 427-440. 